\title{
Prediction of Self-Concept by Trait Anxiety and Basic Values in Childhood Period
}

Necla ACUN KAPIKIRAN ${ }^{\mathrm{a}^{*}}$ (ORCID ID - 0000-0003-3671-4644)

Aysun GÜNDOĞAN ${ }^{\mathrm{b}}$ (ORCID ID - 0000-0002-9521-1577)

${ }^{a}$ Pamukkale Üniversitesi Eğitim Fakültesi Denizli/Türkiye

${ }^{b}$ Pamukkale Üniversitesi Acıpayam Meslek Yüksek Okulu, Denizli/Türkiye

\section{Article Info}

DOI: $10.14812 /$ cufej. 693790

Article history:

Received 25.02.20

Revised 31.05.21

Accepted 27.10.21

Keywords:

Self-concept,

Trait anxiety,

Basic values,

Childhood

\begin{abstract}
The aim of this study is to examine the contributions of self-transcendence, conservatives, self-enhancement, openness to change and trait anxiety in predicting the self-concept of individuals in middle childhood. The data of this research were collected from $4^{\text {th }}$ and $5^{\text {th }}$ grade students in middle childhood. A total of 218 students, $108(49.5 \%)$ female and 110 (50.5\%) male, of the participants of the study. Demographic information form, Pier-Harris Self-Concept Scale, Trait Anxiety Scale and Portrait Values Scale were applied to the participants. The obtained data were tested with hierarchical regression analysis. As a result of the analysis of the data, trait anxiety significantly predicted the unhappiness, anxiety, maladaptive, intellect and love-popularity sub-dimensions of the self-concept. Basic values significantly predicted some sub-dimensions of self-concept. As a result of testing the scores they got in the sub-dimensions of self-concept between boys and girls, while girls scored high in the physical, intellect and popularity sub-dimensions of self-concept, boys got higher scores only in the maladaptive sub-dimension. The results are discussed in the context of trait anxiety and basic values literature

\section{Değerlerce Yordanması}

\section{Öz}

Bu çalışmanın amacı orta çocukluk dönemindeki bireylerin öz aşkınlık, korumacılık, öz genişletme, değişime açıklık temel değerler ve sürekli kaygının bireylerin benlik kavramını yordamadaki katkılarının incelenmesidir. Bu araştırmanın verileri, orta çocukluk dönemindeki 4 . ve 5. sınıf öğrencilerinden toplanmıştır. Çalışmanın katılımcılarının 108'i (\% 49,5) kız ve 110'u (\% 50.5) erkek olmak üzere toplam 218 öğrencidir. Katılımcılara demografik bilgi formu, Pier-Harris Benlik Kavramı Ölçeği, Sürekli Kaygı Ölçeği ve Portre Değerler Ölçeği uygulanmıştır. Elde edilen veriler hiyerarşik regresyon analizi ile test edilmiştir. Verilerin analizi sonucunda, sürekli kaygının benlik kavramının mutsuzluk, kaygı, uyumsuzluk, zihinsel ve sevgi-popülerlik alt boyutlarını anlamlı düzeyde yordamıştır. Temel değerler benlik kavramının bazı alt boyutlarını anlamlı olarak yordamıştır. Kız ve erkekler arasında benlik kavramının alt boyutlarında aldıkları puanların test edilmesi sonucunda, kızlar benlik kavramının fiziksel, zihinsel ve popülerlik alt boyutlarında yüksek puan alırken erkekler yalnızca uyumsuzluk alt boyutunda daha yüksek puan elde etmişlerdir. Sonuçlar sürekli kaygı ve temel değerler alan yazını çerçevesinde tartışılmıştır
\end{abstract}

\begin{tabular}{|c|c|}
\hline \multicolumn{2}{|c|}{ Makale Bilgisi } \\
\hline \multicolumn{2}{|c|}{ DOI: 10.14812/cufej.693790 } \\
\hline \multicolumn{2}{|c|}{ Makale Geçmişi: } \\
\hline Geliş & 25.02 .20 \\
\hline Düzeltme & 31.05 .21 \\
\hline Kabul & 27.10 .21 \\
\hline
\end{tabular}

Anahtar Kelimeler: Benlik kavramı, Sürekli kaygı, Temel değerler, Çocukluk 


\section{Introduction}

The development of a child's self-concept begins to be more realistic in middle/late childhood than in the previous period. In early childhood, children define themselves mostly with physical characteristics, while in middle-late childhood, children begin to define themselves with existence, competence and moral characteristics (Montemayor \& Eisen, 1975). Interactions with important and valuable people in the child's life have a great impact on their development of self-concept. These interactions contribute to the formation of the child's self-concept (Savelson, Hubner, \& Stanton, 1976). As the child interacts with new individuals in his/her life, changes occur in his/her self-concept. In this process, the child reconstructs his/her self-concept by combining experiences with new interactions as well as past experiences. Parents also who have a significant impact on children's self-concept. Their positive interaction with their children positively affects the child's self-concept. For example, when parents talk to their children about negative events in the past, they positively affect children's selfperceptions (Reese, Bird, \& Tripp, 2007). When children repeat their negative experiences in their past lives, they can provide more information about the event. This may affect their perspective on the event. In the development of self-concept, both others' and one's own evaluations of the individual affect the self-concept (Savelson, Hubner, \& Stanton, 1976). In other words, self-concept is not formed solely by the individual's positive or negative experiences in interaction with others. At the same time, the individual, as an active being, can make restruction by filtering his/her experiences. Self-concept is related to a set of phenomena in which the child defines and evaluates himself/herself. For example, it includes perceptions such as "I am a successful person", "I am a loved one" and "I run well". The child's positive self-image depends on the child's internalization or externalization of the feedback as well as the positive feedback from the people nearby (Baer, Kim, \& Wilkenfe, 2012).

\section{Self-Concept and Trait Anxiety}

Children's self-concepts or self-perceptions are negatively affected by stressful life events and anxiety. Anxiety has biological (Grantham-Mc Gregor \& Ani, 2001; Sameroff, Seifer, Barocas, Zax \& Greenspan, 1987), psycho-social and cultural sources (Alisinanoğlu \& Ulutaş, 2003; Çakmak, Özkale, Yıldırım \& Kanadlı, 2019). Long-term stressful events can lead to the development of an anxious personality in children. Trait anxiety, which is "the feeling of dissatisfaction and unhappiness that occurs as a result of the individual's perception of neutral situations as dangerous and self-threatening" (Öner \& Lecompte, 1985:1-2), is one of the most negative emotional states that children can experience. Individuals with trait anxiety tend to perceive or interpret their situations as stressful. Children with trait anxiety may perceive even neutral situations as dangerous and self-threatening (Özusta, 1995). Some children may experience trait anxiety and fear throughout their development. They may be anxious about different events and phenomena depending on their age For example, in childhood, the child's anxiety is about whether or not to be accepted by his/her friends, while in his/her youth, this anxiety may be replaced by work-related concerns. Therefore, children who have a lot of anxious experiences in middle childhood may experience other anxieties with changing directions in the future (Bover, 1976). In a study by Sümer and Şendağ, (2009), a negative relationship was found between positive self-concepts and trait anxiety of children in middle childhood.

\section{Self Concept and Basic Values}

Values have a central role in defining an individual's self-concept and identity. The individual reflects his/her original self through his/her own values (Hitlin, 2003) which are beliefs associated with one's feelings. Values are defined as principles that lead to relatively important behavior according to a certain standard which directs behavior to achieve desired goals (Schwartz, 2009:2). The individual is affected by social life in the process of socialization. As the individual is affected by social life, $s /$ he can also affect social life (Schwartz, 1999). For example, while the child learns how to interact with other 
people in the family, the principles that the family introduces to the child may accompany the child's behavior. When parents share their principles with their children, children are likely to learn how and in what situations they should act. When parents share the principles that accompany their behavior with their children, they should consider that children can act according to these principles and when children understand why these values are necessary, these principles are transferred from parents to children (Knafo \& Assor, 2007). In addition to the transfer of values by parents, the socio-culturaleconomic situation of the countries is effective in determining the values. For example, in a study by Schwartz, Sagiv, and Boehnke (2000), conversation (security, conformity, and tradition) and selfenhancement (hedonism, success, and power) emerge as a value priority in developing countries countries while openness to change (self-direction, stimulation and hedonism) and self-transcendence (universalism and benevolence) values are prominent in developed countries.Value priorities of societies as well as individuals can change. A study by Schwartz (2012) found that there is a difference between developed and developing countries in terms of individual and social values. Although Turkey is a developing country, there are differences between the economic, educational and social-psychological characteristics of families. These differences may cause differences in the development of children (e.g., anxiety, self-concept, values). In other words, in countries where economic differences are high, there may be differences in values among individuals. Self-transcendent values are values that create macrolevel anxiety related to the problems of society and the world. Conservative values, on the other hand, are values related to anxiety at the micro (individual) level (Schwartz, Sagiv, \& Boehnke, 2000; Schwartz, 2012). However, when values related to openness to change (hedonism, stimulation, and self-direction) are compared with self-enhancement values (hedonism, power, achievement), openness to change is related to one's growth and development needs independent of individual anxiety whereas selfenhancement values (achievement) and power) are related to the individual concerns (Schwartz, 2006).

The micro and macro social environment in which individuals live has an important effect on the development of individuals. According to these results, it can be accepted as an expected situation that the micro/macro environment in which people live has the power to influence and transform school-age children (Narvaez, 2006). Considering that the child's relationships in the micro environment (family, etc.) and the child's self-perceptions' importance in development, the child's interaction with his/her parents in the early period will form the basis of the child's first relationships. The positive or negative orientation of the parents in their interaction may increase or decrease the development of positive or negative characteristics in the child's personality. The child's experiences in an anxious family and punishing parental behaviors may cause him/her to develop an anxious trait (Baer, Kim, \& Wilkenfe, 2012). These experiences of the child can have a negative impact during childhood or in the years after childhood (Najman, Hayatbakhsh, Clavarino, Bor, O'Callaghan, \& Williams, 2010). For example, the selfconcept of a child who grows up in a stressful family may not develop well (Sümer \& Şendağ, 2009). Stressful events/poverty can cause children to experience more stress and depression in their lives. Children may not always develop negatively in situations of high stress such as poverty/negative living conditions. Despite the adverse living conditions, the quality of the interaction in the childmother/father relationship may lead to the healthy development of the child, and the quality of the interaction may have a protective function in the child's development (Li, Liang, Yin, \& Zhang, 2018).

Most of the studies on values have been carried out on young and adult individuals (Demirutku \& Sümer, 2010; Koruklu \& Yalçın, 2011; Oğuz, 2012). Studies on values in childhood are relatively new (Bubeck \& Bilsky, 2004; Döring, 2008, 2010; Döring, Blauensteiner, Aryus, Drögekamp, \& Bilsky, 2010; Knafo \& Spinath, 2011; Lee, Ye, Sneddon, Collins, \& Daniel, 2017). Considering the middle childhood period as a period in which children's self-perceptions and values begin to develop, the findings on the 
relationship between self-concept, values and anxiety in this period will contribute theoretically and practically to children's education and adjustment. Many studies have revealed that children's values begin to form in the early years. These studies are mostly related to the development and adaptation of scales. (Bubeck and Bilsky, 2004; Döring, 2008, 2010, Döring, Blauensteiner, Aryus, Drögekamp and Bilsky, 2010; Kapıkıran \&Gündoğan, 2016, 2018; Knafo and Spinath, 2011; Lee et al., 2017). Values first begin to form and develop in the family and affect the child's behavior from early years (Whitbeck \& Gecas, 1988). Moreover, in family interaction, not only parents affect children, but also children can affect parents' values (Knafo \& Galansky, 2008). Childhood years are the period in which there is considerable learning in the development of children. In the development of the child's self-concept in middle-late childhood, trait anxiety and basic values constitute an important emotional-social development area. Few studies have been found in the literature on the relationship between children's self-concepts and trait anxiety (Sümer \& Şendağ, 2009). However, if the relationship between children's values and self-concept is determined, it will allow us to know how the values acquired by children will contribute to the development of their self-concept. Considering all these reasons, in this study, the subdimensions of self-concept in middle-late childhood is aimed to test the predictive power of the trait anxiety and self -transcendence, conservation, self-enhancement, openness to change basic values and some demographical variables.

\section{Method}

\section{Participants}

Schools in the city center in Aegean region were preferred while choosing the participants. In order to collect the data in a reliable way, data were collected from the children attending the schools in the center because there is a relationship between reading comprehension and socioeconomic level (Kuşdemir \& Karabay, 2012). Although the schools are in the center, the residential areas of the schools reflect different socio-economic levels. The prices of houses in different neighborhoods where schools are located are taken as social economic indicators (Küçükkaplan \& Aldı, 2017). For this purpose, schools reflecting the lower, middle and upper socio-economic levels were selected. Participants consisted of 218 people (Grade 4-5; $69 \%-31 \%$, respectively). 108 (49.5\%) of the participants were female and 110 $(50.5 \%$ ) were male. The ages of the participants were between 9-11 (Mean=10.5, S= 0.73). As to the educational status of parents; mother's education as $10 \%$ primary school or less education years, $11 \%$ as secondary school, $18 \%$ as high school and $37 \%$ as university graduates. On the other hand, $7 \%$ of the fathers are primary school graduates, $15 \%$ are secondary school graduates, $19 \%$ are high school graduates and $43 \%$ are university graduates. The rate of children who did not mark the educational status of their parents is $24 \%$.

\section{Measuring Tools}

\section{Demographic information form}

Demographic information form was prepared by the first author. It includes questions that determine the age, gender, class and parental educational status of the students. In the information form, students' age $\left(9,10,11,12\right.$ years), gender (girl and boy), grade level $\left(4-5^{\text {th }}\right.$ grade) and parental education levels (literate, not literate, primary school, secondary school, university and graduate) were given categorically.

\section{Self concept scale for children}

The Children's Self-Concept Scale (CSCS) was developed by Piers and Harris in 1969. The scale is applied to students in the 9-16 age group. The scale measures the self-concepts of children and young people and includes 80 items with "yes" and "no" answers. It is a measurement tool consisting of six sub-dimensions: happiness, anxiety, maladaptive, physical, intellect, and love-popularity. The first 
Turkish translation of the scale was made by Çataklı (1985). Later, Öner (1994) verified the validity and reliability of the scale. In the validity study of the scale, factor analysis was performed first and it was calculated that the scale had 6 factors and explained $42 \%$ of the variance. The discriminant validity of the scale was carried out with the test anxiety inventory. The correlations of the scale with test anxiety were found at the level of $r=-0.43$ for the $4^{\text {th }}$ grades and $r=-0.46$ for the $5^{\text {th }}$ grades. While the Cronbach's alpha coefficient for the reliability of the scale was 0.85 for the $4^{\text {th }}$ graders, it was calculated as 0.87 for the $5^{\text {th }}$ grades. The test-retest reliability of the scale, which was performed at 6 -day intervals for primary schools, was reported as $r=0.82$ (Öner, 1994). In this study, the Cronbach's alpha coefficient of the scale items was calculated as $\alpha=0.73$.

\section{Trait anxiety inventory for children}

The Trait Anxiety Inventory for Children (CTAI) was developed by Spielberger (1973). The scale is a 20-item self-report instrument that aims to measure individual differences in anxiety predisposition. It requires a triple rating of 'almost never', 'sometimes' and 'often'. The Turkish adaptation of the scale was carried out by Özusta (1995). As a result of the comparison of psychiatric group and normal children in the Turkish adaptation study carried out with normal children in the 9-12 age group, a significant difference was noted in terms of trait anxiety scores. Trait anxiety scores of children who received psychiatric treatment were found to be higher than normal children who did not receive treatment. Cronbach's alpha coefficient was calculated for the internal consistency of the inventory. The alpha coefficient of the trait anxiety scale was calculated as $\alpha=0.81$. The test-retest reliability of the scale at $6-$ week intervals was found to be 0.74 . For this study, the Cronbach's alpha coefficient of the scale was calculated as $\alpha=0.83$.

\section{Values scale for children}

The Portrait Values Scale (PVS) was developed by Bubeck and Bilsky (2004). The scale is a 21-item self-report and 6-point Likert-type measurement tool. It is a scale that aims to measure the value structures of 10-12, 13-14 and 15-17 age groups. PVS was adapted into Turkish by Kapıkıran and Gündoğan (2016). As a result of the confirmatory factor analysis for the construct validity of the scale, RMSEA $=.043$, SRMR $=.072, \mathrm{CFI}=.93$ and NNFI $=.91$. Internal consistency reliability of PBL was calculated with Cronbach's alpha. Internal consistency coefficients for the sub-dimensions of the scale are as follows; $\alpha=0.73$ for self-transcendent values subscale, $\alpha=0.65$ for conservative values subscale, $\alpha=.60$ for self-enhancement values subscale, $\alpha=0.65$ for openness to change subscale, and was calculated as 0.87 for all scale items. The Cronbach's alpha coefficient calculated for this study is $\alpha=$ 0.73 for all scale scores.

\section{Process}

The students whose data were collected in the study are located in schools in different settlement areas in terms of the socio-economic level of the city. Three different socio-economic levels were determined as lower middle upper taking into account the prices of the houses in the neighborhoods where the schools are selected according to the settlement areas of the city and the taxes determined by the municipality according to the settlement areas. Data were collected from $4^{\text {th }}$ and $5^{\text {th }}$ grade students. The students were selected on a voluntary basis. Before applying the scales to the designated classes, the students were asked to consult their parents whether they would approve of their children's participation in this study. The scales were administered to the children who were approved for compliance and they were given to children in small groups of 3-4 people. The children were taken in groups of 3-4 in a quiet and suitable room where there were no other children so that they would not be affected by others. Necessary explanations were made before the children filled in the scales. The children filled in the scale items and the questionnaire items in time periods varying between 20 and 30 
ACUN KAPIKIRAN \& GÜNDOĞAN - Çukurova Üniversitesi Eğitim Fakültesi Dergisi, 50(2), 2021, 591-613

minutes. The data were analyzed with the SPSS-22 package program. Descriptive statistics, Pearson

Product Moments correlation and hierarchical regression analysis were used for data analysis.

\section{Results}

Table 1.

Descriptive statistics and correlations of all variables

\begin{tabular}{|c|c|c|c|c|c|c|c|c|c|c|c|c|c|c|c|}
\hline Variables & $\bar{x}$ & Ss & 1 & 2 & 3 & 4 & 5 & 6 & 7 & 8 & 9 & 10 & 11 & Skewness & kurtosis \\
\hline 1-Unhappy & 1,71 & 1,9 & - &, $616(* *)$ &, $618\left(^{* *}\right)$ &,- 042 &,$- 286^{* *}$ &,$- 532 * *$ &, $543^{* *}$ &,$- 186^{* *}$ &,$- 225^{* *}$ & , 020 & ,006 & ,018 & 1,818 \\
\hline 2-Anxiety & 3,72 & 2,2 & & - &, $556(* *)$ &,- 101 &,$- 186^{* *}$ &,$- 384 * *$ &, $599 * *$ &,$- 196 * *$ &,$- 163^{*}$ &,- 051 &,- 026 & 033 & ,007 \\
\hline 3-Maladaptive & 3,15 & 1,97 & & & - &,- 068 &,$- 269 * *$ &,$- 353^{* *}$ &, $336 * *$ &,$- 172 *$ &,$- 197^{* *}$ & 123 & 086, & 1,454 & 3,182 \\
\hline 4-Psysical & 6,09 & 1,40 & & & & - & ,204** & ,186** &,- 069 & 079 &, $134^{*}$ &, 051 & ,096 & 652 & 2,485 \\
\hline 5- Intellect & 5,00 & 1,09 & & & & & - & ,464** &,$- 213^{* *}$ &, $241 * *$ &, $180^{* *}$ &, $232 * *$ &, $201^{* *}$ & 1,577 & 196 \\
\hline $\begin{array}{l}\text { 6-Love- } \\
\text { popularity }\end{array}$ & 8,59 & 1,67 & & & & & & $x^{2}$ &,$- 440 * *$ &, $242^{* *}$ & , 168* &, $224 * *$ & ,099 & $-1,209$ & 2,417 \\
\hline 7-Trait Anx, & 11,84 & 6,20 & & & & & & & - &,$- 168^{*}$ &,$- 176 * *$ &,- 106 &,- 054 &,- 753 &,- 233 \\
\hline $\begin{array}{c}\text { 8- Self } \\
\text { trancendence. }\end{array}$ & 24,97 & 5,05 & & & & & & & & - & ,689** &, $535 * *$ &, $607^{* *}$ & $-1,535$ & 967 \\
\hline 9.Conservatie & 27,45 & 5,79 & & & & & & & & & - & ,493** &, $513^{* *}$ & ,242 &,- 205 \\
\hline $\begin{array}{l}\text { 10-Self- } \\
\text { enhanc. }\end{array}$ & 21,45 & 4,67 & & & & & & & & & & - & ,628** & $-1,160$ &,- 411 \\
\hline $\begin{array}{l}\text { 11- Openress } \\
\text { to change }\end{array}$ & 23,27 & 4,85 & & & & & & & & & & & - & -,586 &,- 504 \\
\hline
\end{tabular}

As seen in Table 1, there was a moderate negative correlation between unhappiness a subdimension of self-concept which is the dependent variable of the study and trait anxiety which is one of the independent variables, and a low level of negative correlation between self-transcendence and conservative values. While there was a positive and significant relationship between the anxiety dimension of the self-concept and trait anxiety, a low negative correlation was found between the values of self-transcendence and conservative values. There was a positive and low relationship between self-concept maladaptivity and trait anxiety with self-transcendence and conservative values. A low-level significant positive correlation was found only between the physical dimension of the selfconcept and the conservative value. While there is a low negative relationship between the intellect dimension of self-concept and trait anxiety, there is a positive and low significant relationship with the values of self-transcendence, conservative, self-enhancement and openness to change. An average negative correlation was found between the popularity/love dimension of the self-concept and trait anxiety. There was a negative and low-level significant relationship between the self-concept love/popularity sub-dimension and the values of self-transcendence, conservative and selfenhancement values. A negative and moderately significant relationship was found between trait anxiety and self-transcendence and conservative values (Table-1). There is a significant relationship between the sub-dimensions of self-concept and trait anxiety and basic values among the independent variables. Based on these relationships, the data were analyzed by regression analysis to determine to what extent the independent variables of trait anxiety and basic values predicted the sub-dimensions of self-concept.

\section{Hierarchical Regression analysis of Self-Concept Trait Anxiety and Values}

Hierarchical regression analysis was conducted to determine the predictive power of gender, SES, trait anxiety and basic values for the sub-dimensions of children's self-concept. 
ACUN KAPIKIRAN \& GÜNDOĞAN - Çukurova Üniversitesi Eğitim Fakültesi Dergisi, 50(2), 2021, 591-613

Table 2.

Prediction of sub-dimensions of self-concept by gender, school trait anxiety and basic values

\begin{tabular}{|c|c|c|c|c|c|c|c|c|c|c|c|c|}
\hline \multirow{2}{*}{ Independent variables } & \multicolumn{2}{|c|}{ Unhappy } & \multicolumn{2}{|c|}{ Anxiety } & \multicolumn{2}{|c|}{ Maladaptive } & \multicolumn{2}{|c|}{ Physical } & \multicolumn{2}{|c|}{ Intellect } & \multicolumn{2}{|c|}{ Love-popularity } \\
\hline & $\beta$ & $\mathrm{t}$ & $\beta$ & $\mathrm{t}$ & $\beta$ & $\mathrm{t}$ & $\beta$ & $\mathrm{t}$ & $\beta$ & $\mathrm{t}$ & $\beta$ & $\mathrm{t}$ \\
\hline $\begin{array}{cc}\text { 1. Step } \\
\text { Gender }(\mathbf{1}-\mathbf{F}, \mathbf{0}-\mathbf{M})\end{array}$ &,- 043 &,- 638 & -,027 &,- 404 &,- 146 & $-2,164^{*}$ & 154 & $2,290^{*}$ & ,228 & $3,437 * *$ & 143 & $2,124^{*}$ \\
\hline $\begin{array}{l}\text { 2. Step } \\
\text { Gender }\end{array}$ &,- 052 &,- 777 &,- 035 &,- 529 &,- 155 & $-2,395^{*}$ & 156 & $2,321^{*}$ & ,235 & $3,632 * * *$ & 153 & $2,350 *$ \\
\hline School Lower SES & 243 & $3,098 * * *$ & 247 & $3,138 * *$ & ,255 & $3,340 * *$ &,- 040 &,- 509 &,- 266 & $-3,489 * * *$ &,- 294 & $-3,831 * * *$ \\
\hline School Upper SES &,- 030 &,- 380 &,- 081 & $-1,035$ & ,046 & ,598 &,- 064 &,- 804 & 164 & 2,154 & ,048 & ,620 \\
\hline $\begin{array}{l}\text { 3.Step } \\
\text { Gender }\end{array}$ &,- 093 & $-1,631$ &,- 081 & $-1,484$ &,- 179 & $-2,897 * *$ & 162 & $2,404^{*}$ & .244 & $3.89 * * *$ & 185 & $3,112 * *$ \\
\hline School Lower SES & 060 & ,864 & 044 & 658 & 149 & 1,957 &,- 014 & -163 & .203 & $2.58 * *$ &,- 152 & $-2,076^{*}$ \\
\hline School Upper SES & 060 & 891 & 019 & 287 & 098 & 1,336 &,- 077 & -961 & .133 & 1.75 &,- 023 &,- 321 \\
\hline Trait Anxiety &, 535 & $8,980 * * *$ &, 594 & $10,399 * * *$ & 312 & $4,824 * * *$ &,- 079 & $-1,115$ & .184 & $-2.75 * *$ &,- 417 & $-6,710 * * *$ \\
\hline $\begin{array}{l}\text { 4.Step } \\
\text { Gender }\end{array}$ &,- 068 & $-1,198$ &,- 063 & $-1,145$ &,- 141 & $-2,357^{* *}$ & 167 & $2,43 * *$ & ,256 & $4,017 * * *$ & 189 & $3,184 * *$ \\
\hline School Lower SES & 052 & 717 & 022 & 314 & 169 & $2,198^{*}$ & 014 & 164 &,- 121 & $-1,470$ &,- 106 & $-1,384$ \\
\hline School Upper SES & 039 & ,583 & 011 & 173 & ,068 & 964 &,- 073 & -906 & ,125 & 1,662 &,- 029 &,- 410 \\
\hline Trait Anxiety & 511 & $8,675^{* * *}$ &, 581 & $10,05 * * *$ & ,282 & $4,539 * * *$ &,- 075 & $-1,049$ &,- 178 & $-2,674 * *$ &,- 405 & $-6,546 * * *$ \\
\hline Self-transendence &,- 089 & $-1,013$ &,- 147 & $-1,719$ &,- 147 & $-1,591$ &,- 090 &,- 854 & 074 & ,753 & ,126 & 1,373 \\
\hline Openness to change & 094 & 1,192 & 076 & 977 & 188 & $2,246 *$ & 091 & 947 & 045 &, 507 &,- 125 & $-1,497$ \\
\hline $\mathrm{F}$ & & 407 & & 163 & & $4,682^{*}$ & & $5.24 *$ & & $11.81 * * *$ & & $4.51^{*}$ \\
\hline 1. Step & & & & & & & & & & & & \\
\hline 2. Step & & $4.07^{*}$ & & $5.51 *$ & &, $7.989 * * *$ & & 2.36 & & $8.22 * *$ & & $7.41 * *$ \\
\hline 3. Step & & $24.35^{* * *}$ & & $30.99 * * *$ & & $12,432^{* * *}$ & & 2.08 & & $8.25^{* *}$ & & $17.96 * * *$ \\
\hline 4. Step & & $14.41^{* * *}$ & & $16.08^{* * *}$ & & $10,340 * * *$ & & 1.50 & & $5.73^{* *}$ & & $10.63^{* * *}$ \\
\hline $\begin{array}{c}\text { R2 } \\
\text { 1.Step }\end{array}$ & .002 & & ,001 & & ,017 & & ,024 & & ,052 & &, 020 & \\
\hline 2.Step & .054 & & ,047 & & ,088 & & ,032 & & 103 & & ,094 & \\
\hline 3.Step & .314 & & ,368 & & 174 & &, 038 & & ,134 & & ,252 & \\
\hline 4.Step & .356 & & ,381 & &, 256 & &, 055 & & ,180 & & ,289 & \\
\hline
\end{tabular}

Note. ${ }^{*} p<0.05 * * p<0.01 * * * p<0.001$

Table 2 shows the level of predicting the sub-dimensions of self-concept of independent variables such as gender, school, trait anxiety and basic values. In the hierarchical regression analysis, firstly gender was entered in the first stage, schools were entered in the second stage, trait anxiety was entered in the third stage, and self-enhancement, openness to change, conservative and selftranscendence values were entered in the fourth stage. Table 2 lists the variables that predict selfconcept. According to these results, lower SES, trait anxiety, conservative and self-enhancement values, which are among the socio-economic levels of the schools, significantly predicted the unhappiness subdimension of the self-concept. The lower SES, trait anxiety, conservative and self-enhancement values, which are among the socio-economic levels of the schools, explain approximately $36 \%$ of the total variance regarding the unhappiness dimension of the self-concept. According to these results, the variable that most explains the self-concept unhappiness dimension is trait anxiety.

School and trait anxiety variables significantly predicted the anxiety dimension of self-concept. These variables explained $38.1 \%$ of the total variance. The variable that most explained the anxiety dimension of the self-concept was trait anxiety.

Gender, school, trait anxiety, conservative, self-enhancement and openness to change variables significantly predicted the maladaptive dimension of the self-concept. These independent variables were calculated to explain approximately $26 \%$ of the total variance. When examined in terms of the 
contribution of each variable that constitutes the total predictive power to the variance, it was observed that $.017 \%$ were explained by gender (male), $071 \%$ by school, $086 \%$ by trait anxiety and $082 \%$ by basic values.

Only gender significantly predicted the physical dimension of self-concept. In the physical dimension of self-concept, gender (girls) explained $055 \%$ of the variance. Gender, school, trait anxiety and core values significantly predicted the intellect dimension of self-concept. These variables (gender, school, trait anxiety and core values) explained $18 \%$ of the total variance in the intellect dimension of selfconcept. The variables that contribute most to the intellect dimension are respectively; gender $052 \%$, lower SES school $051 \%$, trait anxiety $031 \%$ and basic values $046 \%$. Gender, school, trait anxiety and self-enhancement values significantly predicted the popularity/love dimension of the self-concept. These variables explained $28.9 \%$ of the total variance. It was seen that the variable that contributed most to the popularity/love dimension of the self-concept was trait anxiety.

\section{Discussion}

In this study, the sub-dimensions of self-concept in middle-late childhood is aimed to test the predictive power of the trait anxiety and self -transcendence, conservative, self-enhancement, openness to change basic values and some demographical variables.

As a result of the analysis carried out to determine the variables that predicted the sub-dimensions of self-concept, all the dimensions of the self-concept were predicted by the independent variables. According to the order in which the predictor variables are presented, firstly, the predictive power of the gender variable will be discussed. Gender significantly predicted maladaptive, physical, intellect and love/popularity sub-dimensions of self-concept. It positively predicted all the other dimensions of selfconcept except the maladaptive sub-dimension. In other words, while boys scored higher on the maladaptive dimension, girls scored higher on the intellect, physical, and love/popularity dimensions. According to these results, it can be said that female students' self-concepts are more positive than males. However, in a study conducted by Sümer and Şendağ (2009), they found a result in favor of men only in the physical sub-dimension. The result in favor of girls in the current study may have resulted from the early physical development of girls before puberty.

The second variable that predicts the sub-dimensions of self-concept is school. Considering the relationship between self-concept and school, all sub-dimensions of self-concept except the physical dimension were predicted significantly by the school. Low socio-economic level school's self-concept positively predicted the unhappiness, anxiety and maladaptive sub-dimensions whereas it negatively and significantly predicted the intellect and love-popularity sub-dimensions of the medium, and high SES schools. The predictive power of the physical sub-dimension is not significant. This finding is consistent with the literature (Landis, Hayman, \& Hall, 1971). Children with low socio-economic status have a more negative self-perception (Baer, Kim, \& Wilkenfe, 2012; Chiu \& Klassen, 2010). According to this result, the most important factor that increases having a negative self-perception is poverty that contributes negatively to the development of self-concept of children in middle childhood. Low SES can increase the individual's perceptions of being unhappy, anxious, and maladaptive. On the contrary, it positively predicted the mental and love-popularity dimensions of high SES. According to this result, the higher the SES, the more individuals perceive their mental side as a more positive and loved one.

Another variable that tests the predictive power on the sub-dimensions of self-concept is trait anxiety. Trait anxiety predicted all dimensions except the physical dimension of self-concept. While it positively predicted the unhappiness, anxiety and maladaptive dimensions of the self-concept, it predicted the intellect and love-popularity dimensions negatively. This finding supports the literature 
(Chiu and Klassen 2010; Lee and Hankin, 2009; Riketta, 2004; Sümer and Şendağ, 2009). Environmental factors that cause trait anxiety (malnutrition, stressed mother, poverty, etc.) constitute an important part of anxious experiences in childhood (Grantham-Mc Gregor \& Ani, 2001). Experiencing trait anxiety and fear is seen as experiences that make children's development and adjustment difficulties, and negative experiences may continue to affect the child's whole life (Najman et al., 2010). In a metaanalysis of 18 longitudinal studies on anxiety, Sowislo and Orth (2013) found that there is a relationship between low self-esteem and anxiety. While negative self-concept increases school anxiety among children, it makes them open to change to violence and cyber violence (Escortell Sánchez, Delgado, \& Martínez-Monteagudo, 2020). SES and trait anxiety are variables that negatively affect self-concept. Self-concept and low self-esteem can be seen as both a cause and consequence of anxiety.

Considering the findings on self-concept and basic values; self-enhancement values positively predicted the unhappiness dimension of self-concept, and conservative values negatively predicted it. Self-enhancement values include values associated with hedonism, achievement, and power. Selfenhancement and conservative values are among the values that create micro-anxiety and are more common in developing countries (Schwartz et al., 2000). These results are consistent with the literature. In developing countries, individuals focus more on their individual concerns. As these values emphasize competition more, especially disadvantaged children may have difficulties in adapting to the middleclass norms and values of the society. Conservative values (traditional, conformity and security) are the values that provide happiness for children in this period and they reduce the unhappiness of individuals. In middle childhood, children are most likely to seek approval from adults. Therefore, conformity behavior can be seen more intensely. While openness to change and self-enhancement values predict the maladaptive dimension of the self-concept positively, conservative values predict it negatively. Parents' own value transfers, as well as their parenting attitudes, play an active role in children's gaining age characteristics (Whitbeck, \& Gecas, 1988). The self-enhancement values positively predict the maladaptive dimension of the self-concept. The values of openness to change, on the other hand, consist of values that include hedonism, stimulation, and self-direction. These values can enable individuals to become more autonomous individuals. Self-enhancement values have an aspect that increases dissonance in terms of being a value that encourages the individual to compete with others. In other words, it contributes to maladaptive behaviors in terms of increasing the individual's efforts to be stronger, more successful and to get more pleasure. On the other hand, the conservative values (includes the sub-values of tradition, conformity and security) predict the maladaptive self-concept negatively. According to Piaget and Kohlberg, childhood is a period in which authority (parents, teachers, etc.) is not questioned and "being a good child" is given importance. At this age, obeying authority (parents, teachers, etc.) and being a "good boy" contribute to children's self-concept (Santrock, 1997:328). Conservative values may be important in fostering greater cooperation and friendship for this age group. When competition (success) negatively affects children's relationships, it can also negatively affect their adjustment. Collaborative success is more prominent among school-age children.

Only the self-enhancement values significantly predicted the love/popularity dimension of the selfconcept. Self-enhancement values positively predicted the love/popularity dimension. This result may be due to the age period of the child. In this period, s/he sees self-concept as related to success, friendship, being loved and being popular (Santrock, 1997:328). During this period, the child does not yet try to gain a place in society as an individual. Children with high self-concept popularity and selfenhancement (hedonism, success and power) may be more sought after among their friends as they can assert themselves as successful and powerful. In addition, the success of the child at school and the 
acceptance of friends contribute to the development of self-concept in middle childhood. While the physical and anxiety dimensions of self-concept were not associated with any value, the intellect dimension of self-concept was significantly predicted by four basic values (all). That is, basic values are associated with the intellect self-concept.

\section{Limitations of the Study and Its Theoretical and Practical Implications}

This research has some limitations. The first limitation of the study is that the data of the study were gathered via self-report scales and questionnaires. The data obtained in this aspect are limited to the responses of the participants to the scale and questionnaire. The second limitation is that the study was conducted by collecting data from individuals in a certain age group once. In other words, the study includes cross-sectional research. The third limitation of the study is that it is limited to only three schools located in the center of a province. Considering all these limitations, it may reduce the generalization of the results.

Despite some limitations, the findings of this study have reached some important results in terms of understanding the self-concept of children in middle childhood. According to the results obtained in this study, girls and boys show different development in terms of positive and negative self-concepts. Girls' higher scores in intellect, physical and love/popularity dimensions affect their self-concept positively while boys scored higher in the maladaptive dimension and defined their self-concepts more negatively. In other words, middle childhood girls have a more positive self-concept than boys.

Another contribution of the study is that it reveals that the living conditions of children in middle childhood need to be improved in order for their self-perception to develop in a healthy way. While positive self-concepts predicted middle-upper SES, negative self-concepts predicted lower SES. Another important finding of this study is that trait anxiety affects self-concept negatively among individuals in middle childhood.

On the other hand, the values that parents and school bring to children in middle childhood have shown that they contribute positively to the development of children's self-concept. In particular, it has been revealed that while conservative values reduce children's negative self-concept (unhappiness and maladaptive sub-dimensions), self-enhancement values have a two-way function. In other words, while self-enhancing values (hedonism, success and power) increase the unhappiness of individual, they also contribute to being loved and popular among friends.

As a result, teachers and parents should avoid attitudes and behaviors that will increase children's anxiety. Psychological counselors should carry out psycho-educational activities to reduce children's anxiety. Teachers and parents should be more careful in terms of the values they will bring. Adults should focus on how children are transferred values rather than what values are transferred. In addition, the age group characteristics of the children should be considered while transferring the values.

\section{Ethical approval}

In this study, no action was taken against scientific research and publication ethics by acting in accordance with the Higher Education Institutions Scientific Research and Publication Ethics Directive. 


\section{Türkçe Sürümü}

\section{Giriş}

Orta/geç çocukluk döneminde çocuğun benlik kavramı önceki döneme göre daha gerçekçi olmaya başlar. Erken çocuklukta çocuklar kendilerini daha çok fiziksel özellikler ile tanımlarken, orta-geç çocukluk döneminde çocuklar kendilerini varoluş, yeterlilik ve ahlaki özelliklerle tanımlamaya başlarlar (Montemayor ve Eisen, 1975). Çocuğun benlik kavramının gelişiminde, çocuğun yaşamındaki önemli ve değerli kişilerle gerçekleştirilen etkileşimlerin etkisi büyüktür. Bu etkileşimler, çocuğun benlik kavramının oluşumuna katkı sağlamaktadır (Savelson, Hubner, ve Stanton, 1976). Çocuk yaşamında yeni bireylerle etkileşime girdikçe benlik kavramında değişimler gerçekleşir. Bu süreçte çocuk geçmiş yaşantılarıyla edindiklerinin yanı sıra, yeni etkileşimleri ile edindiği deneyimlerini birleştirerek benlik kavramını yeniden yapılandırır. Ebeveynler, çocukların benlik kavramı üstünde önemli etki yapan kişilerdir. Ebeveynlerin çocuklarıyla olumlu etkileşim içinde olmaları çocuğun benlik kavramını olumlu olarak etkiler. Örneğin ebeveynler çocuklarıyla geçmişteki olumsuz olaylar hakkında tekrar konuştuklarında, çocukların benlik algılarını olumlu olarak etkilerler (Reese, Bird ve Tripp, 2007). Çocuklar geçmiş yaşantılarındaki olumsuz yaşantılarını tekrarladığında olaya ilişkin daha fazla bilgi sağlar. Bu durum çocuğun olaya ilişkin bakış açısını etkileyebilir. Benlik kavramının oluşumunu hem başkaları hem de kişinin kendi değerlendirmeleri etkiler (Savelson, Hubner ve Stanton, 1976). Diğer bir deyişle, benlik kavramı yalnızca bireyin başkalarıyla etkileşimindeki olumlu ya da olumsuz deneyimleriyle oluşmaz. Aynı zamanda, birey etkin bir varlık olarak yaşantıları kendi süzgecinden geçirerek yeniden bir yapılandırma yapabilir. Benlik kavramı, çocuğun kendini tanımladığı ve değerlendirdiği bir dizi olguyla ilişkilidir. Örneğin, ben "Başarılı biriyim”, "Sevilen biriyim" ve "iyi koşarım” gibi algılamaları içerir. Çocuğun kendine ilişkin olumlu imaj oluşturması, yakındaki kişilerin olumlu geri bildirimleri kadar çocuğun geri bildirimleri içselleştirmesine ya da dışsallaştırmasına da bağlıdır (Baer, Kim ve Wilkenfe, 2012).

\section{Benlik Kavramı ve Sürekli Kaygı}

Çocukların benlik kavramları ya da benlik algıları stresli yaşam olaylarından ve kaygıdan olumsuz etkilenir. Kaygının biyolojik (Grantham-Mc Gregor ve Ani, 2001; Sameroff, Seifer, Barocas, Zax ve Greenspan, 1987) psiko-sosyal ve kültürel kaynakları (Alisinanoğlu ve Ulutaş, 2003; Çakmak, Özkale,Yıldırım ve Kanadlı, 2019) vardır. Uzun dönemli stresli olaylar çocuklarda kaygılı bir kişilik gelişimine yol açabilir. Sürekli kaygı, çocukların yaşayabileceği en olumsuz duygu durumlarından birisidir. Sürekli kaygı "nesnel ölçüte göre nötr olan durumların birey tarafından tehlikeli ve özünü tehdit edici olarak algılanması sonucu oluşan hoşnutsuzluk ve mutsuzluk duygusudur" (Öner ve Lecompte, 1985:12). Sürekli kaygılı bireyler, içinde bulundukları durumları genellikle stresli olarak algılama ya da yorumlama eğilimindedir. Sürekli kaygılı çocuklar, nesnel ölçüte göre nötr olan durumları bile tehlikeli ve benliği tehdit edici olarak algılayabilmektedirler (Özusta, 1995). Bazı çocuklar gelişimleri boyunca sürekli kaygı ve korku yaşayabilmektedirler. Çocuklar yaşa bağlı olarak farklı olay ve olgulardan kaygı duyabilirler. Örneğin çocukluk döneminde, çocuğun kaygısı arkadaşları tarafından kabul edilip edilmemek yönünde olurken, gençlik yıllarında bu kaygının yerini işle ilgili kaygılar alabilir. Dolayısıyla orta çocuklukta kaygılı yaşantıları çok olan çocuklar, gelecekte yön değiştirmiş başka kaygılar yaşabilmektedir (Bover, 1976). Sümer ve Şendağ, (2009) tarafından yapılan bir çalışmada, orta çocukluk dönemindeki çocukların olumlu benlik kavramları ile sürekli kaygıları arasında olumsuz ilişki bulmuşlardır. 


\section{Benlik Kavramı ve Temel Değerler}

Bireyin benlik kavramı ve kimliğinin tanımlanmasında değerler merkezi bir role sahiptir. Birey özgün benliğini kendi değerleri aracılı̆ııla yansıtır (Hitlin, 2003). Değerler, kişinin duygularıyla bağlantılı inançlardır. Değerler, arzulanan hedeflere ulaşmak için davranışı belli bir standartlara göre yönlendiren görece önemli davranışlara yol açan ilkeler olarak tanımlanmıştır (Schwartz, 2009:2). Birey sosyalleşme sürecinde sosyal yaşamdan etkilenir. Birey sosyal yaşamdan etkilendiği gibi kendisi de sosyal yaşamı etkileyebilir (Schwartz, 1999). Örneğin, ailede çocuk diğer insanlarla nasıl etkileşimde bulunacağını öğrenirken, ailenin çocuğa kattığı ilkeler çocuğun davranışlarına eşlik edebilir. Ebeveynlerin kendi ilkelerini çocuklarıyla paylaştıklarında, çocukların da hangi durumlarda ve nasıl davranmaları gerektiğini öğrenmeleri olasıdır. Ebeveynler kendi davranışlarına eşlik eden ilkeleri çocuklarıyla paylaşırken çocukların bu ilkelere göre hareket edebileceğini göz önüne alması gerekmektedir. Çocuklar bu değerlerin neden gerekli olduğunu kavradıklarında, bu ilkeler ebeveynlerden çocuklara aktarılmaktadır (Knafo ve Assor, 2007). Değerlerin ebeveynler tarafından aktarılması kadar, ülkelerin sosyo-kültürelekonomik durumu da değerlerin belirlenmesinde etkilidir. Örneğin, Schwartz, Sagiv ve Boehnke (2000) tarafından yapılan bir çalışmada, gelişmekte olan ülkelerde korumacılık (muhafazacılık) (güvenlik, uyma ve geleneksellik) ve öz-genişletme (hazcılık, başarı ve güç) değerleri ön plana çıkarken, gelişmiş ülkelerde değişime açıklık (öz-yönelim, uyarılım ve hazcıık) ve öz-aşkınlık (evrenselcilik ve iyilikseverlik) değerlerinin ön plana çıktığını saptamışlardır. Bireyler kadar toplumların da değer öncelikleri değişebilmektedir. Schwartz (2012) tarafından yapılan bir çalışmada, bireysel ve sosyal değerler bakımından gelişmiş ve gelişmekte olan ülkeler arasında fark olduğunu bulmuştur. Türkiye gelişmekte olan bir ülke olmasına rağmen, ailelerin ekonomik, eğitim ve sosyal-psikolojik özellikleri arasında farklııklar bulunmaktadır. Bu farklııklar, çocukların gelişimlerinde farklılıklar (kaygı, benlik kavramı, değerler vb.) doğurabilmektedir. Diğer bir ifadeyle, ekonomik farklılıkların çok olduğu ülkelerde bireyler arasında değerler bakımdan farklııklar görülebilir. Öz-aşkınlık değerleri toplumun ve dünyanın sorunlarıyla ilişkili makro düzeyde kaygı yaratan değerlerdir. Korumacılık (muhafazacılık) değerler ise daha çok mikro (bireysel) düzeyde kaygıyla ilişkili değerlerdir (Schwartz, Sagiv ve Boehnke, 2000; Schwartz, 2012). Bununla birlikte, yeniliklere açıklıkla ilgili değerler (hazcılık, uyarııım ve öz-yönelim) özgenişletme değerleri (hazcılık, güç, başarı) ile kıyaslandığında, yeniliklere açık olma bireysel kaygıdan bağımsız olarak kişinin büyüme ve gelişme ihtiyaçlarıyla ilişkili iken öz-genişletme değerleri (başarı ve güç) bireyin bireysel kaygılarıyla ilişkilidir (Schwartz, 2006).

Bireylerin içinde yaşadığı mikro ve makro toplumsal çevre, bireylerin gelişimlerinde önemli bir etkiye sahiptir. Bu sonuçlara göre, içinde yaşanılan mikro/makro çevrenin okul çağı çocuklarını etkileme ve dönüştürme gücünün olması (Narvaez, 2006) beklenen bir durum olarak kabul edilebilir. Çocuğun mikro çevresindeki ilişkileri (aile vb.), çocuğun kendilik algısının gelişiminde önem taşıdığı düşünüldüğünde, çocuğun erken dönemde ana-babasıyla etkileşimi, çocuğun ilk ilişkilerinin temelini oluşturur. Anne babanın çocuklarıyla olumlu ya da olumsuz etkileşimi, çocuğun kişiliğinin gelişimini etkileyebilir. Çocuğun kaygılı bir ailedeki deneyimleri ve cezalandırıı ebeveyn davranışları onun da kaygılı bir özellik geliştirmesine neden olabilir (Baer, Kim ve Wilkenfe, 2012). Çocuğun yaşadığı bu deneyimler, çocukluk dönemi ya da çocukluktan sonraki yıllarda olumsuz etki yaratabilir (Najman, Hayatbakhsh, Clavarino, Bor, O'Callaghan ve Williams, 2010). Örneğin, stresli bir ailede yetişen bir çocuğun benlik kavramı sağlıklı gelişmeyebilir (Sümer ve Şendağ, 2009). Stresli olaylar/yoksulluk, çocukların yaşamında daha fazla stres ve depresyon yaşamalarına neden olabilir. Yoksulluk/olumsuz yaşam koşulları gibi stres düzeyi yüksek yaşantıların olduğu durumlarda, çocuklar her zaman olumsuz gelişme göstermeyebilirler. Olumsuz yaşam koşullarına karşın, çocuk-anne/baba ilişkilerindeki etkileşimin kalitesi, çocuğun sağlıkı gelişmesine 
yol açabilir ve etkileşimin niteliği de çocuğun gelişiminde koruyucu bir işleve sahip olabilir (Li, Liang, Yin ve Zhang, 2018).

Değerlere ilişkin çalışmaların büyük çoğunluğu genç ve yetişkin bireyler üzerinde gerçekleştirilmiştir (Demirutku ve Sümer, 2010; Koruklu ve Yalçın, 2011; Oğuz, 2012). Çocukluk dönemindeki değerlere ilişkin araştırmalar görece yenidir (Bubeck ve Bilsky, 2004; Döring, 2008, 2010; Döring, Blauensteiner, Aryus, Drögekamp ve Bilsky, 2010; Knafo ve Spinath, 2011; Lee, Ye, Sneddon, Collins ve Daniel, 2017). Orta çocukluk dönemi, çocukların benlik algılarının ve değerlerinin gelişmeye başladığı bir dönemdir. Bu dönemde, benlik kavramı ile değerler ve kaygı ilişkisinin belirlenmesi, çocukların eğitim ve uyumuna katkı sağlayabilir. Birçok çalışma, çocukların değerlerinin erken yıllardan itibaren oluşmaya başladığını ortaya koymuştur. Bu çalışmalar daha çok ölçeklerin geliştirilmesi ve uyarlanması ile ilgilidir (Bubeck ve Bilsky, 2004; Döring, 2008, 2010, Döring, Blauensteiner, Aryus, Drögekamp ve Bilsky, 2010; Kapıkıran ve Gündoğan, 2016, 2018; Knafo ve Spinath, 2011; Lee ve diğerleri, 2017). Değerler, öncelikle ailede oluşmaya ve gelişmeye başlar. Değerler, erken yıllardan itibaren çocuğun davranışlarını etkiler (Whitbeck ve Gecas, 1988). Dahası aile etkileşiminde yalnızca ebeveynler çocukları etkilemez çocuklar da ebeveynlerin değerlerini etkileyebilir (Knafo ve Galansky, 2008). Çocukluk yılları çocukların gelişiminde azımsanmayacak öğrenmelerin olduğu dönemdir. Orta-geç çocukluk döneminde çocuğun benlik kavramının gelişiminde sürekli kaygı ve temel değerler önemli bir duygusal-sosyal gelişim alanını oluşturmaktadır. Alan yazında, çocukların benlik kavramları ve sürekli kaygı arasındaki ilişkiyle ilgili az sayıda çalışmaya rastlanmıştır (Sümer ve Şendağ, 2009). Oysa çocukların değerleri ile benlik kavramı arasındaki ilişkinin belirlenmesi durumunda, çocukların edindiği değerlerinin benlik kavramlarının gelişimine nasıl katkı sağlayacağını bilmemize olanak sağlayacaktır. Tüm bu gerekçeler göz önünde bulundurularak bu çalışmada, orta-geç çocukluk döneminde öz aşkınlık, korumacılık öz genişletme, değişime açıklık temel değerler ve sürekli kaygı ile bazı demografik değişkenlerin, çocukların benlik kavramlarının alt boyutlarından mutsuzluk, kaygı, uyumsuzluk, fiziksel, zihinsel ve sevgi-popülerlik üzerindeki yordama gücünün sınanması amaçlanmışır.

\section{Yöntem}

\section{Katılımcılar}

Katılımcılar Ege Bölgesindeki bir ilin merkezindeki okullardan seçilmiştir. Verilerin sağlıklı olarak toplanabilmesi için, merkezdeki okullara devam eden çocuklardan veri toplanmıştır. Okuduklarını anlama ile sosyoekonomik düzey arasında ilişki bulunmaktadır (Kuşdemir ve Karabay, 2012). Okulların merkezde olmasına karşın okulların yerleşim alanları farklı sosyo-ekonomik düzeyi yansıtmaktadır. Okulların bulunduğu farklı mahallelerdeki evlerin fiyatları sosyal ekonomik gösterge olarak alınmıştır (Küçükkaplan ve Aldı, 2017). Bu amaçla alt, orta ve üst sosyo-ekonomik düzeyi yansıtan okullar seçilmiştir. Katılımcılar 218 kişiden oluşmaktadır (4-5.sınıf; sırasıyla \%69-\%31). Katılımcıların 108'i (\%49.5) kız ve 110’u (\%50.5) erkektir. Katılımcıların yaşları 9-11 (Ort= 10.5, S= 0. 73) arasındadır. Katılımcıların anne-baba eğitimleri; anne eğitimi \%10 ilkokul ve daha az eğitim yılı, \%11 ortaokul, \%18'si lise ve \%37'si üniversite mezunudur. Babaların ise \%7'si ilkokul, \%15'i ortaokul, \%19'u lise ve \%43'ü üniversite mezunudur. Anne-babaların eğitimini işaretlemeyen çocukların oranı \%24'tür.

\section{Ölçme Araçları}

\section{Demografik bilgi formu}

Demografik bilgi formu birinci yazar tarafından hazırlanmıştır. Öğrencilerin yaş, cinsiyet, sınıf ve anne-baba eğitim düzeylerini belirleyen soruları içermektedir. Bilgi formunda öğrencilerin yaşları 
$(9,10,11,12$ yaş) cinsiyeti (kız ve erkek) sınıf düzeyi (4-5. Sınıf) ve anne-baba eğitim düzeyleri (okur-yazar değil okur-yazar, ilkokul, ortaokul, üniversite ve lisans üstü mezunu) kategorik olarak verilmiştir.

\section{Çocuklar için öz kavram ölçeği}

Çocuklarda Öz Kavram Ölçeği (ÇÖKÖ) Piers ve Harris tarafından 1969 yılında geliştirilmiştir. Ölçek 916 yaş grubundaki öğrencilere uygulanmaktadır. Ölçek çocuk ve gençlerin benlik kavramlarını ölçmekte olup 80 maddeli "evet" ve "hayır" türünde cevaplamayı gerektirmektedir. Mutluluk, kaygı, uyumsuzluk, fiziksel, zihinsel ve sevgi-popülerlik olmak üzere altı alt boyuttan oluşan bir ölçme aracıdır. Ölçeğin ilk Türkçeleştirilmesi Çataklı, (1985) tarafından yapmıştır. Daha sonra Öner (1994) ölçeğin geçerliğini ve güvenirliğini gerçekleştirmiştir. Ölçeğin geçerlik çalışmasında öncelikle faktör analizi yapılmış ölçeğin 6 faktörlü olduğu ve varyansın \% 42'sini açıkladığı hesaplanmıştır. Ölçeğin ayırt edici geçerliği sınav kaygısı envanteri ile gerçekleştirilmiştir. Ölçeğin sınav kaygısı ile korelasyonları 4 . sınıflar için, $r=-0.43,5$. sınıflar için $r=-0.46$ düzeyinde bulunmuştur. Ölçeğin güvenirliği için yapılan Cronbach alfa katsayısı 4. sınıflar için $\alpha=0.85$ bulunurken, 5 . sınıflar için $\alpha=0.87$ olarak hesaplanmıştır. Ölçeğin ilkokullar için 6 gün arayla yapılan test tekrar test güvenirliği $r=0.82$ olarak rapor edilmiştir (Öner, 1994). Bu çalışmada ölçek maddelerinin Cronbach alfa katsayısı $\alpha=0.73$ olarak hesaplanmıştır.

\section{Çocuklar için sürekli kaygı envanteri}

Çocuklar için Sürekli Kaygı Envanteri (SKE) Spielberger (1973) tarafından geliştirilmiştir. Ölçek kaygı yatkınlığında bireysel farkları ölçmeyi amaçlayan ve 20 maddeden oluşan öz -bildirime dayalı bir araçtır. 'Hemen hemen hiç', 'bazen' ve 'sık sık' olmak üzere üçlü derecelemeyi gerektirmektedir. Ölçeğin Türkçeye uyarlaması Özusta (1995) tarafından gerçekleştirmiştir. 9-12 yaş grubundaki normal çocuklarla gerçekleştirilen Türkçe'ye uyarlama çalışmasında psikiyatrik grupla normal çocukların karşılaşııııması sonucunda, sürekli kaygı puanları açısından anlamlı fark kaydedilmiştir. Psikiyatrik tedavi alan çocukların tedavi almayan normal çocuklara göre sürekli kaygı puanları daha yüksek olarak bulunmuştur. Envanterin iç tutarlığı için Cronbach alfa katsayısı hesaplanmıştır. Sürekli kaygı ölçeğinin alfa katsayısı $\alpha=$ 0.81 olarak hesaplanmıştır. Ölçeğin 6 hafta arayla test tekrar test güvenirliği ise $r=0.74$ olarak bulunmuştur. Bu çalışma için ölçeğin Cronbach alfa katsayısı $\alpha=0.83$ olarak hesaplanmıştır.

\section{Çocuklar için değerler ölçeği}

Portrait Değerler Ölçeği (PDÖ) Bubeck ve Bilsky (2004) tarafından geliştirilmiştir. Ölçek, 21 maddeli öz- bildirime dayalı ve 6'ı likert türü bir ölçme aracıdır. 10-12, 13-14 ve 15-17 yaş gruplarının değer yapılarını ölçmeyi amaçlayan bir ölçektir. PDÖ Türkçe'ye uyarlaması Kapıkıran ve Gündoğan (2016) tarafından yapılmıştır. Ölçeğin yapı geçerliği için yapılan doğrulayııı faktör analizi sonucunda RMSEA = $.043, \mathrm{SRMR}=.072, \mathrm{CFI}=.93$ ve NNFI $=.91$ olarak hesaplanmıştır. PDÖ'nin iç tutarlık güvenirliği Cronbach alfa ile hesaplanmıştır. Ölçeğin alt boyutlarına ilişkin iç tutarlık katsayıları; öz-aşkın değerler alt ölçeği için $\alpha=0.73$, Korumacilık (muhafazaclık) değerleri alt ölçeği için $\alpha=0.65$, öz-genişletme değerler alt ölçeği için $\alpha=0.60$ yeniliklere açıklık değerleri alt ölçeği için $\alpha=0.65$ ve tüm ölçek maddeleri için $\alpha=0.87$ olarak hesaplanmıştır. Bu çalışma için hesaplanan Cronbach alfa katsayısı tüm ölçek puanları için $\alpha=0.73$ 'dir.

\section{iş̧em}

Çalışmanın verilerinin toplandığı öğrenciler, kentin sosyo-ekonomik düzeyi bakımından farklı yerleşim alanlarında bulunan okullarda yer almaktadır. Kentin yerleşim alanlarına göre seçilen okulların yer aldığı mahallelerdeki evlerin fiyatları ve yerleşim alanlarına göre belediye tarafından belirlenmiş vergiler dikkate alınarak alt orta üst olmak üzere üç farklı sosyo-ekonomik düzey belirlenmiştir. Veriler 4 ve 5. sınıf öğrencilerinde toplanmıştır. Öğrenciler gönüllülük esasına göre belirlenmiştir. Belirlenen sınıflara ölçekler uygulanmadan önce, öğrencilerden anne-babalarından bu çalışmaya katılmasına onay verip 
ACUN KAPIKIRAN \& GÜNDOĞAN - Çukurova Üniversitesi Eğitim Fakültesi Dergisi, 50(2), 2021, 591-613

vermeyeceklerine ilişkin olarak sormaları istenmiştir. Uygunluk yönünde onay verilen çocuklara ölçekler uygulanmıştır. Ölçekler, çocuklara 3-4 kişilik küçük gruplar halinde verilmiştir. Çocuklar 3-4 kişilik gruplar halinde başka çocukların olmadığı, diğer çocuklardan etkilenmeyecekleri sessiz ve uygun bir odaya alınmıştır. Çocuklar ölçekleri doldurmadan önce gerekli açıklamalar yapılmışır. Çocuklar ölçek maddeleri ve anket sorularını 20 ile 30 dakika arasında değişen zaman dilimleri içinde doldurmuşlardır. Veriler SPSS-22 paket programıyla analiz edilmiştir. Verilerin analizi için tanımlayıcı istatistikler, Pearson Momentler Çarpımı korelasyonu ve hiyerarşik regresyon analizi kullanılmışıı.

\section{Bulgular}

Bu çalışmada, orta çocukluk dönemindeki çocukların benlik kavramının alt boyutları üstünde sürekli kaygı ve temel değerlerin yordama gücünün belirlenmesi amaçlanmışırı. Bu amaçla bu bölümde benlik kavramının alt boyutları olan; mutsuzluk, kaygı, uyumsuzluk, fiziksel/zihinsel özellikleri, sevilme/popüler olma ile sürekli kaygı ve öz-genişletme, yeniliklere açıkık, korumacı ve öz aşkın değerlerine ait puanlarının aritmetik ortalaması, standart sapması, çarpıklık, basıkık değerleri ve korelasyonları hesaplanmıştır. Tablo 1'de araştırmanın bu değişkenlerine ait betimsel istatistikler yer almaktadır. Daha sonra çocukların benlik kavramı alt boyutları üstünde cinsiyet, okul, sürekli kaygı ve temel değerlerin yordama düzeyini belirlemek amacıyla hiyerarşik regresyon analizi yapılmıştır. Hiyerarşik regresyon analizine yönelik bulgular Tablo 2'de sunulmuştur. Regresyon analizi için demografik değişkenlerden cinsiyetin gölge etkisini (dummy effect) belirlemek amacıyla, kız öğrenciler-1 ve erkek öğrenciler-0 olarak puanlanmıştır. Yine, okullar arasındaki SED farklııklarında gölge etkisini belirlemek için alt SED-1 orta ve üst SED -0 verilerek (okul grup alt SED) veriler düzenlenmiştir. Üst SED etkisini belirlemek için, üst SED-1 ve alt-orta SED-0 verilerek (okul grup üst SED) gruplar oluşturulmuştur (Cohen, 1991).

Tablo-1.

Tüm değişkenlerin betimsel istatistikleri ve korelasyonları

\begin{tabular}{|c|c|c|c|c|c|c|c|c|c|c|c|c|c|c|c|}
\hline Değişkenler & $\bar{x}$ & Ss & 1 & 2 & 3 & 4 & 5 & 6 & 7 & 8 & 9 & 10 & 11 & $\begin{array}{l}\text { Çarpıklı } \\
\text { k }\end{array}$ & Basıklık \\
\hline 1-Mutsuz & 1,71 & 1,9 & - & ,616 & ,618(** & ${ }^{-, 042}$ &,$- 286^{* *}$ &,$- 532^{* *}$ &, $543^{* *}$ &,$- 186^{* *}$ &,$- 225^{* *}$ & ,020 & ,006 & ,018 & 1,818 \\
\hline 2-Kaygı & 3,72 & 2,2 & & - & ,556(**) & -,101 &,$- 186^{* *}$ &,$- 384^{* *}$ & ,599** &,$- 196 * *$ & -,163* & -,051 &,- 026 & ,033 & , 007 \\
\hline 3-Uyumsuz & 3,15 & 1,97 & & & - &,- 068 &,$- 269 * *$ &,$- 353^{* *}$ & ,336** &,$- 172^{*}$ &,$- 197^{* *}$ & 123 & ,086 & 1,454 & 3,182 \\
\hline 4-Fiziksel & 6,09 & 1,40 & & & & - & ,204** & , 186** &,- 069 & 079 & ,134* & 051 & , 096 & ,652 & 2,485 \\
\hline 5-Zihinsel & 5,00 & 1,09 & & & & & - &, $464^{* *}$ &,$- 213^{* *}$ &, $241 * *$ &, $180 * *$ &, $232 * *$ &, $201 * *$ & 1,577 & 196 \\
\hline 6-Sevgi-Pop & 8,59 & 1,67 & & & & & & - &,$- 440^{* *}$ &, $242 * *$ & ,168* &, $224^{* *}$ & ,099 & $-1,209$ & 2,417 \\
\hline 7.Sür.Kay. & 11,84 & 6,20 & & & & & & & - &,$- 168 *$ &,$- 176^{* *}$ &,- 106 &,- 054 &,- 753 &,- 233 \\
\hline 8.Öz aşkın. & 24,97 & 5,05 & & & & & & & & - & ,689** &, $535 * *$ & ,607** & $-1,535$ & 967 \\
\hline 9.Koruma. & 27,45 & 5,79 & & & & & & & & & & ,493** &, $513^{* *}$ & ,242 &,- 205 \\
\hline 10-Öz-geni. & 21,45 & 4,67 & & & & & & & & & & - & ,628** & $-1,160$ &,- 411 \\
\hline 11- Açıklık & 23,27 & 4,85 & & & & & & & & & & & - &,- 586 &,- 504 \\
\hline
\end{tabular}

Not. ${ }^{*} p<0.05 * * p<0.01 * * p<0.000 * * *$

Tablo 1'de görüldüğü gibi çalışmanın bağımlı değişkeni olan benlik kavramının alt boyutlarından mutsuzluk ile bağımsız değişkenlerden sürekli kaygı arasında orta düzeyde, öz aşkınlık ve korumacılık (muhafazacııık) değerleri ile düşük düzeyde olumsuz yönde korelasyon bulunmuştur. Benlik kavramının kaygı boyutu ile sürekli kaygı arasında pozitif yönde anlamlı ilişki bulunurken, öz-aşkınlık ve koruma değerleri ile olumsuz yönde düşük düzeyde ilişki saptanmıştır. Benlik kavramının uyumsuzluk boyutu ile sürekli kaygı arasında olumlu yönde öz aşkınlık ve korumacılık (muhafazacılık) değerleri ile olumsuz yönde ve düşük düzeyde ilişki kaydedilmiştir. Benlik kavramının fiziksel boyutu ile yalnızca korumacılık 
ACUN KAPIKIRAN \& GÜNDOĞAN - Çukurova Üniversitesi Eğitim Fakültesi Dergisi, 50(2), 2021, 591-613

(muhafazacılık) değerleri arasında olumlu yönde düşük düzeyde anlamlı bir ilişki saptanmıştır. Benlik kavramının zihinsel boyutu ile sürekli kaygı arasında olumsuz yönde düşük düzeyde ilişki bulunurken, özaşkınlık, korumacılık (muhafazacılık), öz-genişletme ve değişime açıklık değerleri ile olumlu ve düşük düzeyde anlamlı ilişki bulunmaktadır. Benlik kavramının popülerlik/sevilme boyutu ile sürekli kaygı arasında olumsuz yönde ortalama düzeyde ilişki saptanmıştır. Benlik kavramı sevgi/popülerlik alt boyutuyla öz aşkınlık, korumacılık (muhafazacılık) ve öz genişletme değerleri arasında olumsuz yönde düşük düzeyde anlamlı ilişki kaydedilmiştir. Sürekli kaygı ile öz aşkınlık ve korumacılık (muhafazacılık) değerleri arasında olumsuz yönde ve orta düzeyde anlamlı bir ilişki bulunmuştur (Tablo-1). Benlik kavramının alt boyutları ile bağımsız değişkenlerden sürekli kaygı ve temel değerler arasında anlamlı düzeyde ilişki vardır. Bu ilişkilerden hareketle bağımsız değişkenlerden sürekli kaygı ve temel değerlerin benlik kavramının alt boyutlarını ne düzeyde yordadığını belirlemek için regresyon analizi ile veriler çözümlenmiştir.

\section{Benlik Kavramı Sürekli Kaygı ve Değerlere ilişkin Hiyerarşik Regresyon analizi}

Çocukların benlik kavramının alt boyutlarını cinsiyet, SED, sürekli kaygı ve temel değerlerin yordama gücünü belirlemek amacıyla hiyerarşik regresyon analizi yapılmıştır.

Tablo 2.

Benlik kavramının alt boyutlarının cinsiyet okul sürekli kaygı ve temel değerlerce yordanması

\begin{tabular}{|c|c|c|c|c|c|c|c|c|c|c|c|c|}
\hline \multirow[t]{2}{*}{ Bağımsız Değişkenler } & \multicolumn{2}{|c|}{ Mutsuzluk } & \multicolumn{2}{|c|}{ Kaygı } & \multicolumn{2}{|c|}{ Uyumsuzluk } & \multicolumn{2}{|c|}{ Fiziksel } & \multicolumn{2}{|c|}{ Zihinsel } & \multicolumn{2}{|c|}{ Sevgi Popülerlik } \\
\hline & $\beta$ & $\mathrm{t}$ & $\beta$ & $T$ & $\beta$ & $\mathrm{t}$ & $\beta$ & $\mathrm{t}$ & $\beta$ & $\mathrm{t}$ & $\beta$ & $\mathrm{t}$ \\
\hline 1. Aşama & & & & & & & & & & & & \\
\hline $\begin{array}{l}\text { Cinsiyet (1- } \\
\mathrm{K}, 0-\mathrm{E})\end{array}$ &,- 043 &,- 638 &,- 027 &,- 404 &,- 146 & $-2,164^{*}$ & 154 & $2,290^{*}$ & 228 & $3,437^{* *}$ & 143 & $2,124^{*}$ \\
\hline $\begin{array}{l}\text { 2. Aşama } \\
\text { Cinsiyet }\end{array}$ &,- 052 &,- 777 &,- 035 &,- 529 &,- 155 & $-2,395^{*}$ & 156 & $2,321^{*}$ & 235 & $3,632^{* * *}$ & 153 & $2,350^{*}$ \\
\hline Okul Grup Alt SED & 243 & $3,098^{* * *}$ & 247 & $3,138^{* *}$ & 255 & $3,340^{* *}$ &,- 040 &,- 509 &,- 266 & $3,489 * * *$ & -294 & $-3,831^{* * *}$ \\
\hline Okul Grup Üst SED &,- 030 &,- 380 &,- 081 & $-1,035$ & ,046 & ,598 &,- 064 &,- 804 & 164 & 2,154 & ,048 & ,620 \\
\hline $\begin{array}{l}\text { 3.aşama } \\
\text { Cinsiyet }\end{array}$ &,- 093 & $-1,631$ &,- 081 & $-1,484$ & -179 & $-2,897^{* *}$ & 162 & $2,404^{*}$ & .244 & $3.89^{* * *}$ & 185 & $3,112^{* *}$ \\
\hline Okul Grup Alt SED & ,060 & 864 & 044 & 658 & 149 & 1,957 &,- 014 & -163 & .203 & $2.58^{* *}$ &,- 152 & $-2,076^{*}$ \\
\hline Okul Grup Üst SED & ,060 & 891 & ,019 & 287 & 098 & 1,336 &,- 077 & -961 & .133 & 1.75 & -023 & - 321 \\
\hline Sürekli Kaygı & ,535 & $8,980^{* * *}$ & ,594 & $\begin{array}{c}10,399 * * \\
*\end{array}$ & ,312 & $4,824^{* * *}$ &,- 079 & $-1,115$ & .184 & $-2.75^{* *}$ &,- 417 & $-6,710^{* * *}$ \\
\hline $\begin{array}{l}\text { 4.aşama } \\
\text { Cinsiyet }\end{array}$ &,- 068 & $-1,198$ &,- 063 & $-1,145$ & -141 & $-2,357^{* *}$ & 167 & $2,43^{* *}$ & 256 & $4,017^{* * *}$ & 189 & $3,184^{* *}$ \\
\hline Okul Grup Alt SED & ,052 & 717 & ,022 & 314 & 169 & $2,198 *$ & 014 & 164 &,- 121 & $-1,470$ &,- 106 & $-1,384$ \\
\hline Okul Grup Üst SED & ,039 & ,583 & 011 & 173 & 068 & 964 &,- 073 & -,906 & 125 & 1,662 &,- 029 &,- 410 \\
\hline Sürekli Kaygı & ,511 & $8,675^{* * *}$ & ,581 & $10,05^{* * *}$ & 282 & $4,539 * * *$ &,- 075 & $-1,049$ &,- 178 & $-2,674^{* *}$ &,- 405 & $-6,546 * * *$ \\
\hline Öz- aşkınlık &,- 089 & $-1,013$ &,- 147 & $-1,719$ &,- 147 & $-1,591$ &,- 090 &,- 854 & ,074 & ,753 & 126 & 1,373 \\
\hline $\begin{array}{c}\text { Korumacilık } \\
\text { (muhafazacılık) }\end{array}$ &,- 175 & $-2,206^{*}$ &,- 012 & -160 &,- 192 & $-2,304^{*}$ & 137 - - & 1,424 &,- 020 &,- 227 &,- 075 &,- 899 \\
\hline Öz-genişletme & 161 & $2,143^{*}$ & ,050 & 680 & ,250 & $3,160^{*}$ &,- 023 &,- 252 & 158 & 1,865 & 212 & $2,697^{* *}$ \\
\hline Yaşantılara açıklık & ,094 & 1,192 & ,076 & 977 & 188 & $2,246^{*}$ & 091 & 947 & 045 & 507 & - 125 & $-1,497$ \\
\hline $\mathrm{F}$ & & ,407 & & 163 & & $4,682 *$ & & $5.24 *$ & & $11.81 * * *$ & & $4.51^{*}$ \\
\hline 1.aşama & & & & & & & & & & & & \\
\hline 2.aşama & & $4.07 *$ & & $5.51^{*}$ & & $\begin{array}{c}, 7.989 * * \\
*\end{array}$ & & 2.36 & & $8.22^{* *}$ & & $7.41^{* *}$ \\
\hline 3. aşama & & $24.35^{* * *}$ & & $30.99 * * *$ & & $\begin{array}{c}12,432^{* *} \\
*\end{array}$ & & 2.08 & & $8.25 * *$ & & $17.96 * * *$ \\
\hline 4. aşama & & $14.41^{* * *}$ & & $16.08^{* * *}$ & & $\begin{array}{c}10,340 * * \\
*\end{array}$ & & 1.50 & & $5.73^{* *}$ & & $10.63^{* * *}$ \\
\hline $\begin{array}{c}\mathrm{R} 2 \\
\text { 1.aşama }\end{array}$ & .002 & & ,001 & & 017 & & ,024 & & , 052 & & , 020 & \\
\hline
\end{tabular}




\begin{tabular}{llllll} 
2.aşama & .054 &, 047 &, 088 &, 032 &, 103 \\
3. aşama & .314 &, 368 &, 174 &, 038 &, 134 \\
4.aşama & .356 &, 381 &, 256 &, 055 &, 180 \\
\hline
\end{tabular}

Not $.^{*} p<.05^{* *} p<.01^{* * *} p<. .001$

Tablo-2'de bağımsız değişkenlerden cinsiyet, okul, sürekli kaygı ve temel değerlerin benlik kavramının alt boyutlarını yordama düzeyi görülmektedir. Yapılan hiyerarşik regresyon analizinde ilk olarak birinci aşamada cinsiyet, ikinci aşamada okullar, üçüncü aşamada sürekli kaygı ve dördüncü aşamada özgenişletme, yeniliklere açıklık, korumacılık ve öz aşkın değerleri girilmiştir. Tablo 2 de benlik kavramını yordayan değişkenler sıralanmıştır. Bu sonuçlara göre, okulların sosyo ekonomik düzeylerinden alt SED, sürekli kaygı, korumacılık ve öz genişletme değerleri benlik kavramının mutsuzluk alt boyutunu anlamlı düzeyde yordadığı görülmüştür. Okulların sosyo ekonomik düzeylerinden alt SED, sürekli kaygı, korumacılık ve öz genişletme değerleri, benlik kavramının mutsuzluk boyutunun \% 36'sını açıklamıştır. Bu sonuçlara göre, benlik kavramı mutsuzluk boyutunu en fazla açıklayan değişken sürekli kaygıdır.

Okul ve sürekli kaygı değişkenleri benlik kavramının kaygı boyutunu anlamlı bir düzeyde yordamıştır. Bu değişkenler toplam varyansın \% 38.1'ini açıklamıştır. Benlik kavramının kaygı boyutunu en fazla açıklayan değişken sürekli kaygı olmuştur.

Benlik kavramının uyumsuzluk boyutunu cinsiyet, okul, sürekli kaygı, korumacılık (muhafazacılık) özgenişletme ve yaşantılara açıklık değişkenleri anlamlı düzeyde yordamıştır. Bu bağımsız değişkenler yaklaşık olarak toplam varyansın $\% 26$ 'sını açıklamıştır. Toplam yordama gücünü oluşturan her bir değişkenin varyansa katkısı bakımından incelendiğinde; \% .017'sini cinsiyet (erkek), \% 071'ni okul, \% 086'sını sürekli kaygı ve \% .82'sini temel değerlerin açıkladığı görülmüştür.

Benlik kavramının fiziksel boyutunu yalnızca cinsiyet anlamlı bir düzeyde yordamıştır. Benlik kavramının fiziksel boyutunda cinsiyet (kızlar) varyansın \% .055'ini açıklamıştır.

Benlik kavramının zihinsel boyutunu cinsiyet, okul, sürekli kaygı ve temel değerler anlamlı olarak yordamıştır. Benlik kavramının zihinsel boyutunu toplam varyansın \% 18'ini bu değişkenler (cinsiyet, okul, sürekli kaygı ve temel değerler) açıklamıştır. Zihinsel boyuta en fazla katkısı olan değişkenler sırasıyla; cinsiyet \% .052, alt SED okul \% .051, sürekli kaygı \% .031 ve temel değerler \% .046'dir.

Cinsiyet, okul, sürekli kaygı ve öz genişletme değerleri benlik kavramının popülerlik/sevilme boyutunu anlamlı bir düzeyde yordamıştır. Bu değişkenler toplam varyansın \% 28,9'unu açıklamıştır. Benlik kavramının popülerlik/sevilme boyutuna en fazla katkı yapan değişkenin sürekli kaygı olduğu görülmüştür.

\section{Tartışma}

Bu çalışmada okul çağı çocuklarında sürekli kaygı, temel değerler ve bazı demografik değişkenlerin çocukların benlik kavramının alt boyutlarını ne düzeyde yordayıcı olduğunun belirlenmesi amaçlanmıştır.

Benlik kavramının alt boyutlarını yordayan değişkenleri belirlemek üzere yapılan analiz sonucunda benlik kavramının bütün boyutları bağımsız değişkenlerce yordanmıştır. Yordayıcı değişkenlerin veriliş sırasına göre ilk olarak cinsiyet değişkenin yordayıcılığı tartışılacaktır. Cinsiyetin benlik kavramının uyumsuzluk, fiziksel, zihinsel ve sevgi/popülerlik alt boyutlarını istatistiksel olarak anlamlı olarak yordamıştır. Uyumsuzluk boyutunda erkekler daha yüksek puan alırken, kızlar zihinsel, fiziksel ve sevgi/popülerlik boyutunda daha yüksek puan elde etmişlerdir. Bu sonuçlara göre, kız öğrencilerin benlik kavramının alt boyutları erkeklere göre daha olumlu olduğu söylenebilir. Bununla beraber, Sümer ve Şendağ (2009) tarafından yapılan bir çalışmada sadece fiziksel alt boyutunda erkekler lehinde bir sonuç bulmuşlardır. Oysa, mevcut çalışmada kızların benlik kavramı daha olumludur. Bu durum, kızların ergenlik öncesindeki erken fiziksel gelişiminden kaynaklanabilir. 
Benlik kavramının alt boyutlarıı yordayan ikinci değişken okuldur. Benlik kavramı ve okul arasındaki ilişkiye bakıldığında, fiziksel boyut hariç benlik kavramının tüm alt boyutları okul tarafından anlamlı olarak yordanmıştır. Alt sosyo-ekonomik düzeydeki okulun benlik kavramının mutsuzluk, kaygı ve uyumsuzluk alt boyutlarını olumlu, orta ve yüksek SED okulların zihinsel ve popülerlik-sevilme alt boyutlarını olumsuz ve anlamlı düzeyde yordamıştır. Fiziksel alt boyutun yordama gücü anlamlı düzeyde değildir. Bu bulgu alan yazınla tutarlılık göstermektedir (Landis, Hayman ve Hall, 1971). Düşük sosyoekonomik düzeydeki çocukların benlik algısı daha olumsuzdur (Baer, Kim ve Wilkenfe, 2012; Chiu ve Klassen, 2010). Bu sonuca göre, olumsuz benlik algısına sahip olmayı artıran en önemli faktörün başında yoksulluk gelmektedir. Yoksulluk orta çocukluk dönemindeki çocukların benlik kavramının gelişimine olumsuz yönde katkıda bulunmaktadır. Düşük SED bireyin mutsuzluk, kaygııı olma ve uyumsuz olma algılarını artırabilmektedir. Tersine yüksek SED'in zihinsel ve popülerlik-sevilme boyutlarını olumlu yönde yordamıştır. Bu sonuca göre, SED yükseldikçe bireyler kendilerini zihinsel olarak olumlu ve sevilen birisi olarak algılamaktadırlar.

Benlik kavramının alt boyutları üstünde yordama gücünün sınandığı bir diğer değişken de sürekli kaygıdır. Sürekli kaygı benlik kavramının fiziksel boyutu hariç diğer tüm boyutları yordamıştır. Sürekli kaygının benlik kavramının mutsuzluk, kaygı ve uyumsuzluk boyutlarını olumlu yönde yordarken zihinsel ve popülerlik-sevilme boyutlarını olumsuz yönde yordamışır. Bu bulgu alan yazını destekler niteliktedir (Chiu and Klassen 2010; Lee ve Hankin, 2009; Riketta, 2004; Sümer ve Şendağ, 2009). Sürekli kaygıya yol açan çevresel faktörler (yetersiz beslenme, stresli anne, yoksulluk vb) çocukluk çağındaki kaygılı deneyimlerin önemli bir kısmını oluşturmaktadır (Grantham-Mc Gregor ve Ani, 2001). Sürekli kaygı ve korku yaşamak çocukların gelişimlerini ve uyumlarını güçleştiren yaşantılar olarak görülmekte ve olumsuz yaşantıların yaşam boyu çocuğun yaşamını etkilemeye devam edebilmektedir (Najman ve diğerleri, 2010). Sowislo ve Orth'un (2013) kaygıyla ilgili 18 boylamsal çalışmanın meta analizini yaptıkları çalışmada, düşük öz saygı ile kaygı arasında ilişki olduğunu bulmuşlardır. Olumsuz benlik kavramı çocuklarda okul kaygısını artıııken şiddet ve siber şiddete maruz kalmaya açık hale getirmektedir (Escortell Sánchez, Delgado, ve Martínez-Monteagudo, 2020). SED ve sürekli kaygı benlik kavramını olumsuz etkileyen değişkenlerdir. Benlik kavramı ve benlik saygııının düşüklüğü kaygının hem nedeni hem de sonucu olarak görülebilir.

Benlik kavramı ve temel değerlere yönelik bulgulara bakıldığında; benlik kavramının mutsuzluk boyutunu, öz genişletme değerleri olumlu ve korumacı değerler olumsuz olarak yordamıştır. Özgenişletme değerleri hazcılık, başarı ve güç ile ilişkili değerleri içermektedir. Öz-genişletme ve korumacılık (muhafazacılık) değerleri mikro kaygı yaratan ve gelişmekte olan ülkelerde daha çok ortaya çıkan değerler arasında yer almaktadır (Schwartz ve diğerleri, 2000). Bu sonuçlar alan yazınla tutarlıdır. Gelişmekte olan ülkelerde bireyler daha çok bireysel kaygılarına odaklanmaktadırlar. Bu değerler rekabeti daha fazla vurguladığı için özellikle dezavantajlı çocuklar toplumun orta sınıf normları ve değerlerine uyum göstermede güçlükler yaşamalarına neden olabilir. Korumacılık değerleri bireylerin mutsuzluğunu azaltmaktadır. Korumacılık değerleri (geleneksellik, uyma ve güvenlik), bu dönemdeki çocuklar için mutluğu sağlayan değerlerdir. Orta çocukluk döneminde, çocuklar büyüklerin onayını en fazla almaya çalıştıkları dönemdir. O nedenle, uyma davranışı daha yoğun görülebilmektedir.

Benlik kavramının uyumsuzluk boyutunu yaşantılara açıklık ve öz-genişletme değerleri olumlu olarak yordarken korumacılık değerleri olumsuz olarak yordamıştır. Çocukların yaş dönemi özelliklerini kazanmasında anne-babaların çocuk yetiştirme tutumları kadar anne-babaların kendi değer aktarımları da etkin bir role sahiptir (Whitbeck, ve Gecas,1988). Benliğin uyumsuzluk boyutunu olumlu yönde yordayan hazcılık, başarı ve güç değerlerini içeren (öz genişletme değeri) temel bir değerdir. Yaşantılara 
açıklık değeri ise hazcılık, uyarılım ve kendi yönelimli olmayı içeren değerlerden oluşmaktadır. Bu değerler bireylerin daha özerk bireyler haline gelmesini sağlayabilir. Öz genişletme değerleri bireyin başkalarıyla rekabet etmesini teşvik eden bir değer olması bakımından uyumsuzluğu artıran bir yönü bulunmaktadır. Diğer bir deyişle, bireyin daha güçlü daha başarılı olmasını ve daha haz almaya dönük çabalarını artırmaya dönük olması bakımından uyumsuzluğa katkı sağlamaktadır. Diğer taraftan uyumsuzluk boyutunu tersi yönde yordayan korumacılık değerleri; geleneksellik, uyma ve güvenlik alt değerlerini içermektedir. Piaget ve Kohlberg'e göre çocukluk yetkenin (ana-baba, öğretmen vb) sorgulanmadığı "iyi çocuk olma" nın önemsendiği bir dönemdir. Bu yaş döneminde, otoriteye (annebaba, öğretmen vb) biat etmek, "iyi çocuk" olmak çocukların benlik kavramlarına katkı sağlamaktadır (Santrock, 1997:328). Korumacılık değerleri bu yaş grubu için daha fazla işbirliği ve arkadaşlık sağlamada önemli olabilir. Rekabet (başarı) çocukların ilişkilerini olumsuz yönde etkilediğinde uyumunu da olumsuz etkileyebilir. Okul çağı çocukları arasında iş birliğine dayalı başarı daha ön plana çıkmaktadır.

Benlik kavramının sevgi/popülerlik boyutunu sadece öz genişletme değeri olumlu yönde yordamıştır. Bu sonuç, çocuğun yaş döneminden kaynaklanabilir. Bu dönemde benlik kavramıı başarı, arkadaşlık, sevilme, popüler olma gibi faktörler etkin bir rol oynar (Santrock, 1997:328). Çocuk bu dönemde henüz birey olarak toplumda yer edinmeye çalışmaz. Benlik kavramının popülerlik boyutu ile öz-genişletme boyutu (hazcılık, başarı ve güç) yüksek olan çocuklar, başarılı ve güç sahibi olarak kendilerini ortaya koyabildikleri oranda arkadaşları arasında daha aranan olabilirler. Ayrıca, orta çocuklukta benlik kavramının gelişimine çocuğun okuldaki başarısı ve arkadaş kabulü de önemli bir role sahiptir.

Benlik kavramının fiziksel ve kaygı boyutları hiçbir değerle ilişkili olmazken benlik kavramıın zihinsel boyutu, dört temel değerler (tümü) tarafından anlamlı olarak yordanmıştır. Yani, temel değerler zihinsel benlik kavramıyla ilişkilidir.

\section{Araştırmanın Sınırılıkları ve Kuramsal ve Uygulamaya Yönelik Doğurguları}

Bu araştırmanın bazı sınırıııkları bulunmaktadır. Çalışmanın birinci sınırlıı̆ı, çalışmanın verilerinin özbildirime dayalı ölçek ve anketler tarafından elde edilmiş olmasıdır. Bu yönüyle elde edilen veriler katılımcıların ölçek ve ankete verdiği yanıtlarla sınırlıdır. íkinci bir sınırlılığı, çalışma belli bir yaş grubundaki bireylerden bir kez veri toplanmasıyla elde edilmiştir. Diğer bir deyişle çalışma kesitsel bir araştırmayı içermektedir. Çalışmanın üçüncü bir sınırlılığı sadece bir ilin merkezinde yer alan üç okul ile sınırlıdır. Tüm bu sınırlıklar göz önünde bulundurulduğunda sonuçlara ilişkin genellenebilirliği düşürebilir.

Bazı sınırlııklarına karşın bu araştırmadan elde edilen bulgular ile orta çocukluk dönemindeki çocukların benlik kavramını anlamak bakımdan bazı önemli sonuçlara varıımıştır. Bu çalışmada elde edilen sonuçlara göre, kız ve erkekler olumlu ve olumsuz benlik kavramı bakımından farklı yönde gelişim göstermektedirler. Kızların daha çok zihinsel, fiziksel ve sevgi/popülerlik boyutunda yüksek puan elde etmeleri, kızların benlik kavramını olumlu yönde etkilemektedir. Oysa erkekler uyumsuzluk boyutunda daha yüksek puan elde etmişlerdir ve benlik kavramlarının daha olumsuz olarak tanımlamışlardır. Diğer bir deyişle orta çocukluk dönemindeki kızların benlik kavramı erkeklerden daha olumludur.

Çalışmanın katkılarından bir diğeri, orta çocukluktaki çocukların benlik algılarının sağlıklı gelişebilmesi için yaşam koşullarının iyileştirilmesi gerektiğini ortaya koymasıdır. Olumlu benlik kavramını orta-üst SED yordarken olumsuz benlik kavramlarını alt SED'i yordamıştır. Bu çalışmanın önemli diğer bir bulgusu da orta çocukluk dönemindeki bireyler üzerinde sürekli kaygının benlik kavramını olumsuz yönde etkilemesidir.

Orta çocukluk dönemindeki çocuklara ebeveynlerinin ve okulun kazandırdığı değerler, çocukların benlik kavramının gelişimine olumlu yönde katkısının olduğu göstermiştir. Özellikle korumacılık değerlerin çocukların olumsuz benlik algılarını (mutsuzluk ve uyumsuzluk alt boyutlar) azaltırken özgenişletme değerlerinin iki yönlü işleve sahip olduğunu ortaya koymuştur. Yani, öz-genişletme değerleri 
ACUN KAPIKIRAN \& GÜNDOĞAN - Çukurova Üniversitesi Eğitim Fakültesi Dergisi, 50(2), 2021, 591-613

(hazcılık, başarı ve güç) bireylerin mutsuzluğunu artırırken arkadaşlar arasında sevilme-popüler olmaya da katkı sağlamaktadır.

Sonuç olarak, öğretmenler ve ebeveynlerin çocukların kaygısını artıracak bağlamda tutum ve davranışlardan kaçınmaları gerekmektedir. Psikolojik danışmanlar çocukların kaygısını azaltmaya yönelik psiko-eğitim çalışmaları yapmalıdırlar. Yetişkinler çocuklara hangi değerin verildiğinden ziyade nasıl verildiğine odaklanmalıdırlar. Ayrıca, değerlerin verilmesinde çocukların yaş grubu özellikleri dikkate alınmalıdır.

\section{Etik onay}

Bu çalışmada Yükseköğretim Kurumları Bilimsel Araştırma ve Yayın Etiği Yönergesine uygun biçimde hareket edilerek bilimsel araştırma ve yayın etiğine aykırı hiçbir eylem gerçekleşmemiştir.

\section{References}

Alisinanoğlu, F. ve Ulutaş, i. (2003). Çocukların kaygı düzeyleri ile annelerinin kaygı düzeyleri arasındaki ilişkinin incelenmesi. Eğitim ve Bilim, 28(128), 65-71,

Baer, J., Kim, M.S. ve Wilkenfeld, B. (2012). Is it generalized anxiety disorder or poverty? An examination of poor mothers and their children, Child Adolescent Socail Work Journal, 29:345-355

Bover, D.E.I. ( 1976). An explanatory study of developmental changes in children's fears. Journal of Chilid Psychology and Psychiatry, 17, 69-76.

Bubeck, M. ve Bilsky, W. (2004). Value structure at an early age. Swiss Journal of Psychology, 63, 1, 31 41.

Chiu, M. M. ve Klassen, R. M. (2010). Relations of mathematics self-concept and its calibration with mathematics achievement: Cultural differences among fifteen-year-olds in 34 countries. /, /), 2-17.

Cohen, A. (1991). Dummy variables in stepwise regression. The American Statistician, 45(3), 226-228.

Çakmak, , A. G. N., Özkale, U. Yıldırım, Ö. G. M. S. ve Kanadlı, S. (2019) Anne -baba tutumları

ile benlik saygısı arasındaki ilişkinin incelenmesi: Bir meta-analizi çalışması. Educational Science Proceeding Book. 211-229.

Demirutku, K. ve Sümer, N. (2010). Temel değerlerin ölçümü: Portre değerler anketi'nin Türkçe uyarlaması. Türk Psikoloji Yazıları, 13(25), 17-25.

Döring, A. K. (2008). Assetment of children's values: The development of a Picture-based instrument (Unpublished Doctoral Dissertation). University of Münster, Germany.

Döring, A. K. (2010). Assessing children's values: An exploratory study. Journal of Psychoeducational Assessment, 28, 6, 564-577.

Döring, A. K. Blauensteiner, A., Aryus, K., Drögekamp, K. ve Bilsky, W. (2010). Assessing values at an early age: The picture-based value survey for children (PBVS-C) .Journal of Personality Assessment, 92(5), 439-448.

Escortell Sánchez, R., Delgado, B. ve Martínez-Monteagudo, M. C. (2020). Cybervictimization, selfconcept, aggressiveness, and school anxiety in school children: A structural equations analysis. Internatiional Jornal of Enviromental Research and Public Health .doi:10.3390/ijerph17197000

Grantham-McGregor, S. ve Ani, C. (2001). A review of studies on the effect of iron deficiency on cognitive development in children. The Journal of Nutrition, 131(2), 649-668. 
ACUN KAPIKIRAN \& GÜNDOĞAN - Çukurova Üniversitesi Eğitim Fakültesi Dergisi, 50(2), 2021, 591-613

Hitlin, S. (2003). Values as the core of personal identity: Drawing links between two theories of self. Social Psychology Quarterly, 118-137.

Kapıkıran, N. A. ve Gündoğan, A. (2018). Assessment for children's values: Picture-Based value survey for children adaptation study. International Journal of Educational Research Review, 3(2), 9-21.

Kapıkıran, N. A. ve Gündoğan, A. (2016). Çocuk değerlerinin ölçülmesi: Portre değerler ölçeğinin Türkçe'ye uyarlanması. Ege Eğitim Dergisi, (17) 2: 620 - 639.

Kaya, H., Kaya, N., Palloş, A. Ö.,ve Küçük, L. (2012). Assessing time-management skills in terms of age, gender, and anxiety levels: A study on nursing and midwifery students in Turkey. Nurse Education in Practice, 12(5), 284-288.

Knafo, A. ve Assor, A. (2007). Motivation for agreement with parenthal values: Desirable when autonomous, problematic when controlled. Motivation and Emotion, 31, 232-245.

Knafo, A. ve Galansky, N. (2008). The influence of children on their parents' values. Social and Personality Psychology Compass, 2(3), 1143-1161.

Knafo, A. ve Spinath, F.M. (2011). Genetic and environmental influences on girls' and boys' gender typed and gender-neutral values. Developmental Psychology, 47, 3, 726-731.

Kohrt, B. A. ve Worthman, C. M. (2009). Gender and anxiety in Nepal: The role of social support, stressful life events, and structural violence. CNS Neuroscience \& Therapeutics, 15(3), 237-248.

Koruklu, N. veYalçın. Ö. (2011). Üniversite öğrencilerinde değerler ve mutluluk arasındaki ilişkinin incelenmesi. Yüzüncü Yıl Üniversitesi Eğitim Fakültesi Dergisi, 8(1), 190-210.

Kuşdemir- Kayıran, B. ve Karabay, A. (2012). İlkokuma yazmayı farklı yöntemlerle öğrenen ilköğretim beşinci sınıf öğrencilerinin okuduğunu anlama becerileri üzerine bir çalışma. Kuram ve Uygulamada Eğitim Bilimleri, 12(4), 2847-2860.

Küçükkaplan, i. ve Aldı, F. A. (2017). Denizli ilindeki konut fiyatlarına etki eden faktörlerin panel verilerle analizi. Balıkesir Üniversitesi Sosyal Bilimler Enstitüsü Dergisi, 20(37), 219-236.

Landis, D., Hayman, J. L. ve Hall, W. S. (1971). Multidimensional analysis procedures for measuring self-concept in poverty area classrooms. Journal of Educational Psychology, 62(2), 95-103

Lee, A. ve Hankin, B. L. (2009). Insecure attachment, dysfunctional attitudes, and low self-esteem predicting prospective symptoms of depression and anxiety during adolescence. Journal of Clinical Child and Adolescent Psychology, 38, 219-231.

Lee, J. A., Ye, S., Sneddon, J.N., Collins, P.R. ve Daniel, E. (2017). Does the intra-individual structure of values exist in young children? Personality and Individual Differences, 110, 125-130.

Li, C., Liang, Z.,Yin, X. ve Zhang, Q, (2018). . Family social capital mediates the effect of poverty on childrens anxiety and depression. Journal of Community Psychology, 46:983-99.

Metin, N. ve Kangal, S. B.(2012). Bilim sanat merkezine devam eden 12-14 yaş grubu üstün yetenekli çocukların benlik algılarının incelenmesi. Eğitimi ve Bilim, 37(163), 1-16.

Montemayor, R. ve Eisen, M. (1975). The development of self-perceptions in children and adolescents. Paper peresented at the biennial meeting at the Society for Reseach in Child Development, Denver, Colorado, April.

Najman, J.M., Hayatbakhsh, M. R., Clavarino, A. , Bor, W., O’Callaghan M.J., veWilliams, G.M. (2010). Family poverty over the early life course and recurrent adolescent and young adult anxiety and 
ACUN KAPIKIRAN \& GÜNDOĞAN - Çukurova Üniversitesi Eğitim Fakültesi Dergisi, 50(2), 2021, 591-613 depression: A longitudinal study, American Journal of Public Health, (100), 9,1719-1723.

Narváez, D. (2006). Integrative ethical education. In M. Killen ve J. G. Smetana (Eds.), Handbook of Moral Development (pp. 703-732). Mahwah, NJ: Erlbaum.

Oğuz, E. (2012). Öğretmen adaylarının değerler ve değerler eğitimine ilişkin görüşleri. Kuram ve Uygulamada Eğitim Bilimleri, 12(2), 1309-1325.

Öner, N. (1994). Piers-Harris'ın çocuklarda öz-kavramı ölçeği el kitabı. Ankara: Türk Psikologlar Derneği Yay.

Öner, N. ve LeCompe, A. (1985). Durumluk-sürekli kaygı el kitabı. İstanbul: Boğaziçi Üniversitesi Yayınları.

Özusta, Ş. (1995). Çocuklar için durumluk-sürekli kaygı envanteri: Uyarlama, geçerlik ve güvenirlik çalışması. Türk Psikoloji Dergisi, 10(34), 32-44.

Reese, E., Bird, A. ve Tripp, G. (2007). Children's self-esteem and moral self. Links to parent-child conversation regarding emotion. Social Development, 16(3), 460-478.

Riketta, M. (2004). Does social desirability inflate the correlation between self-esteem and anxiety? Psychological Reports, 94, 1232-1234.

Sameroff, A. J., Seifer, R., Barocas, R., Zax, M. ve Greenspan, S. (1987). Intelligence quotient scores of 4-year-old children: Social-environmental risk factors. Pediatrics, 79(3), 343-350.

Santrock, J.W. (1997). Life-span development.USA: The McGraw Hill.

Sarı, M. ve Cenkseven, F., (2008). Illköğretim öğrencilerinde okul yaşam kalitesi ve benlik kavramı. Uluslararası İnsan Bilimleri Dergisi [Bağlantıda]. 5:2. Erişim: http://www.insanbilimleri.com

Savelson, R.J., Hubner, M. ve Stanton, G.C. (1976). Self concept: Validation of costruct interpretations. Review of Educational Research, 46 (3), 407-441.

Schwartz, S.H. (1999). A theory of cultural values and some impilications. Applied Psychology: An International Review, 48(1),23-47.

Schwartz, S.H., Sagiv, L. ve Boehnke, K. (2000). Worries and values. Journal of Personality, 68(2), 309346.

Schwartz, S.H. (2006).Basic human value: An overview. (Les valeurs de base de la personne, theorie, mesures et applications.) Revue francaise de Sociologie, 4(2), 249-288.

Schwartz, S.H. (2009). Basic Human Values. Cross-national comparison seminar on the quality and comparability of measures for constructs in comparative research: Methods and Applications. Bolzano, Italy, June, 10-13.

Schwartz, S. H. (2012). An overview of the Schwartz theory of basic values. Online readings in Psychology and Culture, 2(1), 2307-0919.

Sowislo, J. F. ve Orth, U. (2013). Does low self-esteem predict depression and anxiety? A meta-analysis of longitudinal studies. Psychological Bulletin, 139(1), 213-240.

Spence, S. H. (1998). A measure of anxiety symptoms among children. Behaviour Research and Therapy, $36,545-566$.

Sümer, N. ve Şendağ, M. A. (2009). Orta çocukluk döneminde ebeveynlere bağlanma, benlik algısı ve kaygı. Türk Psikoloji Dergisi, 24(63), 86-101. 
ACUN KAPIKIRAN \& GÜNDOĞAN - Çukurova Üniversitesi Eğitim Fakültesi Dergisi, 50(2), 2021, 591-613

Whitbeck, L. B. ve Gecas, V. (1988). Value attributions and value transmission between parents and children. Journal of Marriage and the Family, 829-840. 